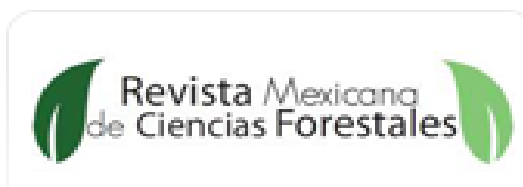

\section{Revista Mexicana de Ciencias Forestales}

ISSN: 2007-1132

ciencia.forestal2@inifap.gob.mx

Instituto Nacional de Investigaciones

Forestales, Agrícolas y Pecuarias

México

Villavicencio Gutiérrez, Eulalia Edith; González Cortes, Areli; Arredondo Gómez, Alberto; Iracheta Donjuan, Leobardo; Comparan Sánchez, Sofía; Casique Valdés, Rebeca MICROPROPAGACIÓN DE Turbinicarpus knuthianus (Boed.) John \& Riha CACTACEA ORNAMENTAL DEL DESIERTO CHIHUAHUENSE, EN ESTATUS DE RIESGO

Revista Mexicana de Ciencias Forestales, vol. 2, núm. 6, julio-agosto, 2011, pp. 37-54 Instituto Nacional de Investigaciones Forestales, Agrícolas y Pecuarias Distrito Federal, México

Disponible en: http://www.redalyc.org/articulo.oa?id=63438961004

Cómo citar el artículo

Número completo

- Más información del artículo

Página de la revista en redalyc.org

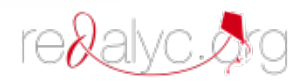

Sistema de Información Científica

Red de Revistas Científicas de América Latina, el Caribe, España y Portugal Proyecto académico sin fines de lucro, desarrollado bajo la iniciativa de acceso abierto 


\title{
MICROPROPAGACIÓN DE Turbinicarpus knuthianus (Boed.) John \& Riha CACTACEA ORNAMENTAL DEL DESIERTO CHIHUAHUENSE, EN ESTATUS DE RIESGO
}

\section{MICROPROPAGATION OF Turbinicarpus knuthianus (Boed.) John \& Riha, ORNAMENTAL CACTUS OF THE CHIHUAHUAN DESERT, AT RISK STATUS}

\author{
Eulalia Edith Villavicencio Gutiérrez', Areli González Cortes², Alberto Arredondo Gómez³, Leobardo Iracheta Donjuan ${ }^{4}$, \\ Sofía Comparan Sánchez y Rebeca Casique Valdés ${ }^{5}$
}

\section{RESUMEN}

Se desarrolló un protocolo en cuatro etapas para la micropropagación de Turbinicarpus knuthianus, una cactácea en estatus de riesgo, para la obtención de plantas de maceta con tamaño comercial uniforme, en cantidades suficientes y con calidad fitosanitaria. El método de propagación propuesto es eficiente comparado con el tradicional; es una nueva tecnología de producción factible de aplicarse en el sistema-producto ornamental, bajo el esquema de laboratorio-invernadero. Las semillas de esta especie son quiescentes y pueden establecerse in vitro en el medio $\mathrm{MS}$ al 50\%, adicionado con $8.65 \mathrm{mM}$ de $\mathrm{AG}_{3}$ con un porcentaje de germinación de 75\%. La inducción de brotes se logró a partir de segmentos de hipocotilo, como explantes, en medio de cultivo MS con diferentes tratamientos. Se determinó que el tipo y concentración de fitohormona influyen en la tasa de multiplicación, y generan hasta 10 brotes por explante; la cinetina (KIN) en interacción 10:1 con AIB en baja concentración es la promotora de este efecto. Durante la aclimatación se observó que la aplicación de $1.5 \times 10^{6} \mathrm{UFC}$ ml- 1 de Azospirillum brasilense tiene un efecto positivo en el proceso rizogénico, de tal manera que se forman hasta 6 raíces por planta con $2.5 \mathrm{~cm}$ de longitud. Con esta metodología es posible regenerar especies en estatus de riesgo de importancia ecológica para el Desierto Chihuahuense y se optimizan los procesos biológicos para la producción de plantas de ornato.

Palabras clave: BA-N6-benzyladenina, cactáceas, inoculación de Azospirillum brasilense, medio Murashige y Skoog, micropropagación, Turbinicarpus knuthianus.

\begin{abstract}
A four stage protocol was developed for the micropropagation of Turbinicarpus knuthianus, an ornamental cactus in risk status, in order to produce plants with standard commercial-sized pots in sufficient amount and good phytosanitary quality. The method here described is efficient compared to the traditional method of propagation; it is a new production technology that can be applied to the ornamental product system under the laboratory-greenhouse scheme. The seeds of this species are quiescent and can be established in vitro on MS medium at $50 \%$ supplemented with $8.652 \mathrm{M}$ of $\mathrm{GA}^{3}$, with $75 \%$ of germination. The induction of shoots and seedlings was obtained by setting segments of explants on MS medium with different treatments. It was determined that the type and concentration of phytohormone affect the multiplication rate and produce as much as 10 shoots/explant; kinetin $(K I N)$ in interaction with ABB 10:1 in low concentrations favors this effect. During the acclimatization stage, it was observed that the application of $1.5 \times 10^{\circ} \mathrm{CFU}$ ml- 1 of Azospirillum brasilense promoted a positive reaction of the rhizogenic process, as much as 6 roots $2.5 \mathrm{~cm}$ long per plant were formed. With this technology, species of ecological importance in risk status can be restored to the Chihuahuan Desert and the biological processes for the production of ornamental plants can be optimized.
\end{abstract}

Key words: BA-N6-benzyladenine, cacti, inoculation of Azospirillum brasilense, Murashige and Skoog medium, micropropagation, Turbinicarpus knuthianus.

Fecha de recepción: 28 de junio de 2011

Fecha de aceptación: 24 de julio de 2011

\footnotetext{
' Campo Experimental Saltillo. CIRNE-INIFAP. Correo-e: villavicencio.edith@inifap.gob.mx

${ }^{2}$ Centro de Capacitación de Tecnología de Granos y Semillas. Universidad Autónoma Agraria Antonio Narro.

${ }^{3}$ Campo Experimental San Luis Potosí. CIRNE-INIFAP.

${ }^{4}$ Campo Experimental Rosario Izapa. CIRPAS-INIFAP.

${ }^{5}$ Departamento. Botánica. Universidad Autónoma Agraria Antonio Narro.
} 


\section{INTRODUCCIÓN}

Turbinicarpus knuthianus (Boed.) John \& Riha, comúnmente llamada "biznaguita" o "biznaga cono invertido de Knuth", es una cactácea pequeña de $6 \mathrm{~cm}$ de diámetro, con tallo esférico, color verde oscuro con espinas agrupadas en aréolas; presenta flores vistosas muy numerosas de $25 \mathrm{~mm}$ de longitud de color carmín rosado brillante. Por su morfología y aspecto es apreciada por coleccionistas expertos y aficionados nacionales y extranieros, quienes la utilizan como planta de ornato (Hunt et al., 2006).

Sus poblaciones naturales se distribuyen en el estado de San Luis Potosí, que forma parte del Desierto Chihuahuense, donde presentan un alto grado de deterioro. Son plantas consideradas endémicas, de lento crecimiento y escasas en su hábitat natural, sujetas a protección especial (Pr), ya que están amenazadas por factores que inciden negativamente en su viabilidad; por lo tanto, es necesario propiciar su recuperación y conservación (SEMARNAT, 2010).

Dado que la flora del país es parte del patrimonio nacional y que es prioritaria su regeneración, sobre todo de aquellas especies con estatus de riesgo, la micropropagación constituye una forma de conservación ex situ, a partir del grado de deterioro que tienen sus poblaciones naturales y el interés que existe por algunos taxa como plantas de ornato, en países europeos y asiáticos.

Los métodos de conservación ex situ se basan en el mantenimiento del material biológico en bancos de semillas, bancos de cultivo in vitro y en colecciones de plantas (en campo, viveros o jardines botánicos). Los dos primeros son de los sistemas más convenientes para el germoplasma, porque permiten almacenar una gran variabilidad genética en forma económica y práctica; sin embargo, en especies como T. knuthianus, cuyas poblaciones son no son de alta densidad y tienen una reducida producción de semillas y de brotes laterales, además de un bajo porcentaje de germinación, es necesario implementar opciones de conservación ex situ como el cultivo de tejidos vegetales (CTV), con el propósito de multiplicarlo, puesto que cuenta con pocos individuos y tiene dificultades para propagarse por métodos convencionales (Villavicencio et al., 2005).

El CTV in vitro o micropropagación se basa en el concepto de totipotencialidad de las células vegetales, es decir, a partir de diferentes explantes es posible desarrollar plantas normales y completas (Moebius-Goldammer et al., 2003). Al respecto, Johnson y Emino (1979a), Hubstenberger et al. (1992) y Giusti et al. (2002) propusieron la propagación clonal a través de la micropropagación, como una vía factible para las cactáceas, con la cual es posible contribuir al rescate y conservación de este recurso fitogenético. Este es un sistema en el que se utilizan como explantes tejidos $u$ órganos que se toman de una o más plantas donadoras, las cuales tienen meristemos preexistentes y a partir de estos se pueden generar uno o más brotes Murashige, 1974; Villalobos y Thorpe, 1985; Pierik, 1987).

\section{INTRODUCTION}

Turbinicarpus knuthianus (Boed.) John \& Riha, known as "biznaguita" or "biznaga cono invertido de Knuth" (Knuth's inverted cone biznaga), is a small cactus of $6 \mathrm{~cm}$ diameter, with a dark green spherical stem, with spines grouped in areolas; it has numerous bright $25 \mathrm{~mm}$ long of carmine-rose flowers. From its morphology and look it is very appreciated by expert collectors as well as by national and foreign amateurs, who use it as an ornamental plant (Hunt, et al. 2006).

Natural populations of the species are distributed in San Luis Potosi State, which is a part of the Chihuahuan Desert, where they suffer great deterioration. They are considered endemic plants of slow growth and scarce in their habitat, are subject to special protection $(\mathrm{Pr})$, since they are threatened by several factors that negatively influence their viability; thus, it is necessary to favor their restoration and conservation (SEMARNAT, 2010).

As flora is part of the national wealth and its regeneration, a priority, particularly of those species at risk status, micropropagation is a way of ex situ conservation, starting from the deterioration that their natural populations have and the prevailing interest for some taxa as ornamental plants in countries of Europe and Asia.

Ex situ conservation methods are based on the preservation of biological material in seed banks, in vitro cultivation banks and in plant collections (in the field, nurseries or botanical gardens). The first two are more convenient systems for germ plasm, since they allow the storage of a great genetic variability in an economic and practical way; however, in species like $T$. knuthianus, that have a scarce density, low seed and lateral shoot production and reduced germination per cent, it is necessary to implement ex situ conservation options such as plant tissue cultures (PTC), in order to multiply it, as it has few individuals and difficulties for propagation by conventional methods (Villavicencio, et. al., 2005).

In vitro PTC or micropropagation is based on the total potentiality concept of vegetal cells, which establishes that it is possible to develop normal and complete plants from explants (Moebius-Goldammer et al., 2003). In this respect, Johnson and Emino (1979a), Hubstenberger et al. (1992) and Giusti et al. (2002) proposed clonal propagation through micropropagation, as a feasible way for Cactaceae, with which it might be possible to contribute to the rescue and conservation of this phytogenetic resource. This is a system in which tissues or organs are used as explants and are taken from one or more donating plants, which have pre-existing meristems and, from them on, shoots can be produced (Murashige, 1974; Villalobos and Thorpe, 1985; Pierik, 1987). 
En cactáceas los brotes se obtienen de yemas axilares que se desarrollan in vitro; estas estructuras están contenidas en areolas o mamilas y su procedencia pueden ser segmentos de plantas de vivero (Vyskot y Jara, 1984; Escobar, 1985; Yassen-Mohamed et. al., 1995), campo (Clayton et al., 1990) y de plántulas germinadas in vitro (Fay y Gratton, 1992).

Algunos autores señalan que en el cultivo de yemas axilares aún existen varias incógnitas por resolver; sin embargo, este método de clonación resulta eficiente en especies útiles como es el caso de T. knuthianus (Rodríguez-Garay y Rubluo, 1992; Hubstenberger et al., 1992).

Dada la importancia ecológica y económica que tiene este recurso fitogenético para las zonas semiáridas del desierto Chihuahuense y para el sector ornamental se desarrolló un protocolo para su micropropagación, en el que también se consideró el efecto que produce el inoculante de Azospirillum brasilense, por ser una bacteria que incide en el proceso rizogénico, como se ha comprobado en Triticum aestivum L., Zea mays L. y en plantas propagadas in vitro como; jojoba, caña de azúcar, papa y mandioca (Carletti et al., 2003; Díaz-Zorita et al., 2004; Okon, 1985).

\section{MATERIALES Y MÉTODOS}

\section{Material genético}

Se utilizaron semillas de una colecta masal de poblaciones naturales ubicadas en los municipios de Guadalcázar, Cerritos y Villa Hidalgo en el estado de San Luis Potosí. En cada localidad se hizo una caracterización del medio físico, que incluyó: la altitud, precipitación, temperatura, textura del suelo, pendiente, orientación de la pendiente y vegetación asociada (Figura 1, Cuadro 1).
In Cactaceae, the shoots are taken from axillary buds that develop in vitro; these structures are contained in areolas and mamillas and their origin might be segments of nursery plants (Vyskot and Jara, 1984; Escobar, 1985; YassenMohamed et al., 1995), field specimens (Clayton et al., 1990) or seedlings germinated in vitro (Fay and Gratton, 1992).

Some authors point out that in axillary bud cultivation there are still several questions to be solved; however, this clonation method probed to be efficient for useful species such as T. knuthianus (Rodríguez-Garay and Rubluo, 1992; Hubstenberger et al., 1992).

Since this phytogenetic resource is important from an ecological and economic stand point for the semiarid zones of the Chihuahuan Desert and for ornamental endings, a protocol for its micropropagation was developed, in which it was considered the effect of Azospirillum brasilense as inoculant since it is a bacterium that affects the rhizogenic process, as has been probed by Triticum aestivum L. and Zea mays L. and in plants propagated in vitro such as jojoba, sugar cane, potatoes and tapioca (Carletti et al., 2003; Díaz-Zorita et al., 2004; Okon, 1985).

\section{MATERIALS Y METHODS}

\section{Genetic Material}

The seeds that were used came from a massal collection taken at locations of natural populations, at Guadalcázar, Cerritos and Villa Hidalgo in San Luis Potosí State. In each location the environment was described through the following data: altitude, precipitation, temperature, soil texture, slope, hillside and associated vegetation (Figure 1, Table 1).

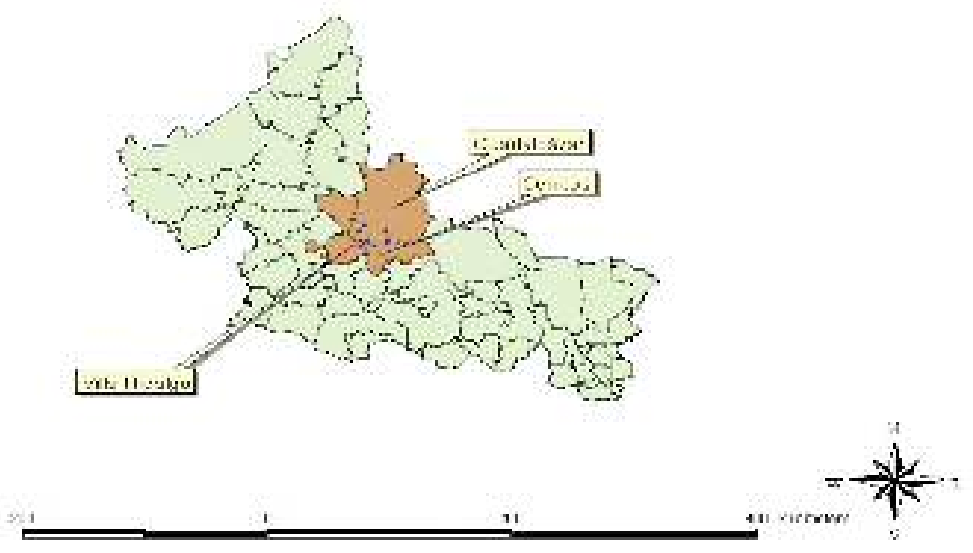

Figura 1. Distribución de Turbinicarpus knuthianus en San Luis Potosí, México.

Figure 1. Distribution of Turbinicarpus knuthianus in San Luis Potosí State, Mexico. 
Cuadro 1. Principales características ecológicas de las poblaciones de Turbinicarpus knuthianus en San Luis Potosí, México. Table 1. Main ecological characteristics of Turbinicarpus knuthianus populations in San Luis Potosí, Mexico.

\begin{tabular}{|c|c|c|c|c|c|}
\hline Clima & Precipitación (mm) & Temperatura & Unidad de suelo & Textura & Altitud (m) \\
\hline \multirow{4}{*}{ BSohw } & & Árido, semicálido & Xerosol háplico & \multirow{4}{*}{ Media } & \multirow[t]{2}{*}{1,500 a 2,000} \\
\hline & Lluvias de verano & $\begin{array}{l}\text { Temperatura de } 18^{\circ} \mathrm{C} \text { y } \\
22^{\circ} \mathrm{C} \text {, Temperatura del } \\
\text { mes más frío }<18^{\circ} \mathrm{C} \text {, }\end{array}$ & & & \\
\hline & \multirow[t]{2}{*}{300 a 400} & $\begin{array}{l}\text { Tempemperatura del mes } \\
\text { más caliente> } 22^{\circ} \mathrm{C} \text {. }\end{array}$ & Xerosol gypsico & & \multirow[t]{2}{*}{1,000 a 1,500} \\
\hline & & $\begin{array}{l}\text { Temperatura máxima } 34 \\
\text { a } 36^{\circ} \mathrm{C}\end{array}$ & & & \\
\hline
\end{tabular}

\section{Etapa 1. Establecimiento de semillas en un cultivo aséptico}

Se evaluó la germinación in vitro de T. knuthianus mediante un diseño experimental completamente al azar con arreglo factorial $2 \times 2$, en el cual se consideró como factor A: dos tipos de medio $\left(\mathrm{MBGl}=0.6 \%\right.$ agar $+87.64 \mathrm{mM}$ de $\mathrm{C}_{22} \mathrm{H}_{22} \mathrm{O}_{11}$ y $M B G 2=\mathrm{MS}$ (Murashige y Skoog, 1962) al 50\%. El factor B consistió en dos tratamientos: $\sin \mathrm{Cl}=0.0 \mathrm{mM}$ de $\mathrm{AG}_{3}$ y con aplicación de ácido giberélico, $\mathrm{C2}=8.65 \mathrm{mM}$ de $\mathrm{AG}_{3}$ adicionado al medio de cultivo como promotor de la germinación. Se usaron semillas de una colecta masal, desinfectadas de acuerdo al protocolo de Villavicencio et al. (2009), con 60 días de colecta, para 30 semillas y tres repeticiones por tratamiento. Las evaluaciones se realizaron cada siete días, durante un período de nueve semanas, las variables consideradas fueron la velocidad (VG) y el porcentaje de germinación (PG).

\section{Etapa 2. Multiplicación o inducción de brotes}

Mediante un diseño experimental completamente al azar con arreglo factorial $2 X 6$ se establecieron segmentos de hipocotilo, obtenido de las plántulas germinadas in vitro, en un medio para la inducción de brotes (MBB), el cual se adicionó con una relación citocinina-auxina 10:1. El factor $\mathrm{A}$ correspondió a los dos tipos de fitohormona (F); cinetina b-furfuryl aminopurina (Kin) y 6-bencil aminopurina (BA). Como factor $B$ se evaluaron seis concentraciones $(C)$ de estas citocininas $(T)=0.46, T 2=0.69$, $\mathrm{T} 3=1.16, T 4=2.32, T 5=3.48$ y $\mathrm{T} 6=4.64 \mathrm{mM}$ de $\mathrm{Kin})$ y (T1=0.44, $T 2=0.66, T 3=1.10, T 4=2.21, T 5=3.30$ y $T 6=4.40 \mathrm{mM}$ de $\mathrm{BA})$, combinadas con su proporción correspondiente de auxina ( $\mathrm{T} 1=0.41, \mathrm{~T} 2=0.61, \mathrm{~T} 3=1.03, \mathrm{~T} 4=2.07, \mathrm{~T} 5=3.1$ y $\mathrm{T} 6=4.13 \times 10^{-1} \mu \mathrm{M}$ de $A(B)$, así mismo se incluyó un tratamiento sin fitohormonas. Como unidad experimental se establecieron tres explantes por frasco con 10 repeticiones por tratamiento. A las ocho semanas se registró el número de brotes (NB) y la altura $(A)$ de los mismos, en mm.
Stage 1. Seed establishment in an aseptic culture

In vitro T. knuthianus germination was assessed through a completely randomized experimental design with a $2 \times 2$ factorial arrangement, in which the following elements were considered as A Factor: $(M B G)=0.6 \%$ agar $+87.64 \mathrm{C}_{12} \mathrm{H}_{22} \mathrm{O}_{11} \mathrm{mM}$ and $M B G 2=M S$ (Murashige and Skoog, 1962). Factor $B$ consisted in two treatments: without $\mathrm{Cl}=0.0 \mathrm{mM}$ de $\mathrm{AG}_{3}$ and with application of gibberellic acid, $C 2=8.65 \mathrm{mM}$ de $\mathrm{AG}_{3}$, which was added to the culture media as a stimulant for germination. The seeds that were used came from a masal collection, were disinfected according to the protocol of Villavicencio et al. (2009), with 60 collection days, 30 seeds and three replications per treatment. Assessments were made every seven days, during a nine week period, the variables were speed (GS) and germination percent (GP).

\section{Stage 2. Shoot multiplicat ion or induction}

Through a completely randomized experimental design with a $2 \times 6$ factorial arrangement hypocotyls, which came from the in vitro germinated seedlings segments, were established in a shoot induction medium (SIM) to which a qitocinine-auxine 10:1 relation was added. Factor $A$ matched the two phytohormone (F) types; kinetine, 6-furfuryl aminopurine (Kin) and 6-Benzyl aminopurine (BA). As factor $B$ six concentrations of these qitocinines (C) were assessed(T1=0.46, T2=0.69, T3=1.16, $\mathrm{T} 4=2.32, T 5=3.48$ y $\mathrm{T} 6=4.64 \mathrm{~m} M$ de $\mathrm{Kin}$ ) and ( $\mathrm{T}=0.44, T 2=0.66$, $T 3=1.10, T 4=2.21, T 5=3.30$ y $T 6=4.40 \mathrm{mM}$ de $B A$ ), combined with their corresponding auxine proportion $(T 1=0.41, T 2=0.67$, $\mathrm{T3}=1.03, \mathrm{~T} 4=2.07, \mathrm{~T} 5=3.1$ y $\mathrm{T} 6=4.13 \times 10^{-1} \mu \mathrm{M}$ de $\mathrm{A} \mathrm{AB}$ ); also, a phytohormone treatment was included. As experimental unit three explants per bottle with 10 replications by treatment were established. After 8 weeks, the number of shoots (SN) and their height $(\mathrm{mm})$ were recorded. 
Condiciones de incubación.- En el Laboratorio de Cultivo de Tejidos Vegetales del Campo Experimental Saltillo del CIRNE-INIFAP se hicieron las dos primeras etapas anteriores. Las semillas se colocaron en tubos Erlenmeyer, con un volumen de $5 \mathrm{~mL}$ de medio de cultivo. Las plántulas se subcultivaron en frascos Gerber ${ }^{(g)}$ de $70 \mathrm{~mL}$ de capacidad, con un volumen de $20 \mathrm{~mL}$ de medio de cultivo. Los subcultivos en la etapa de multiplicación se llevaron a cabo en envases de polipropileno de $500 \mathrm{~mL}$ con un volumen de $50 \mathrm{~mL}$ de medio de cultivo, que se incubaron a una temperatura de $26 \pm 1^{\circ} \mathrm{C}$ y con un fotoperíodo de $16 \mathrm{~h} \mathrm{luz}^{-1}$.

\section{Etapa 3. Enraizamiento y aclimatación}

En el invernadero del Campo Experimental Saltillo del CIRNE-INIFAP se establecieron vitro-plantas del $10 \mathrm{~mm}$ de altura, mediante un diseño experimental completamente al azar con arreglo factorial $4 \times 2$, con tres repeticiones por tratamiento. El factor $\mathrm{A}$ consistió en los cuatro tipos de sustratos (S): S1=arena; $S 2=$ "peat moss"; $S 3=$ negra $y$ S4 = mezcla homogénea de las tres anteriores y el factor B en la inoculación de la cepa de Azospirillum brasilense en dos concentraciones: $\mathrm{CONCl}=1.5 \times 10^{\circ}$ y $\mathrm{CONC} 2=3 \times 10^{\mathrm{U}} \mathrm{UFCl} \mathrm{mL}^{-1}$. Además se contó con un testigo por tipo de sustrato, sin aplicación de la cepa. Las aplicaciones del concentrado de la cepa se realizaron cada siete días, con evaluaciones a los 30 días; las variables consideradas fueron: incremento en altura del tallo (IAT), longitud de raíces (LR) y número de raíces (NR).

La información de las etapas se analizó con el procedimiento GLM del sistema de Análisis Estadístico SAS (2002), mediante la prueba de comparación de medias, con una probabilidad del 95\% para la selección de los tratamientos significativos.

\section{RESULTADOS Y DISCUSION}

\section{Etapa 1. Establecimiento de semillas en un cultivo aséptico}

Porcentaje de germinación (PG). Se obtuvieron diferencias significativas de la interacción $M B G \times C$, con un efecto positivo en proporciones diferentes, al adicionar el promotor de la germinación, el tratamiento MBG2= MS (Murashige y Skoog, 1962) al $50 \%$ + $8.65 \mathrm{~m} M$ de $\mathrm{AG}_{3}$ del que resultó un $P G=75 \%$, mismo que duplicó la emergencia de las vitro-plántulas, con respecto al medio $\mathrm{MBGl}=0.6 \%$ agar $+87.64 \mathrm{mM} \mathrm{C}_{12} \mathrm{H}_{22} \mathrm{O}_{11}+8.65$ $\mathrm{mM}$ de $\mathrm{AG}_{3}$. Esto muestra que en condiciones in vitro T. knuthianus requiere de la adicción de nutrimentos y fitohormonas para promover la imbibición, absorción de oxigeno, activación de enzimas, el transporte de moléculas hidrolizadas hasta el ápice meristemático y con ello activar el proceso de respiración, división celular y alargamiento para el crecimiento de la vitro-plántula.
Incubation conditions.- At the Vegetation Tissue Culture Laboratory of Saltillo Experimental Station of CIRNE-INIFAP the two previous stages were made. The seeds were places in Erlenmeyer tubes, with $5 \mathrm{~mL}$ of culture medium. Seedlings were under cultivated in $70 \mathrm{~mL}$ Gerber ${ }^{(g)}$ bottles, with $20 \mathrm{~mL}$ of culture medium. The under cultivations in the multiplication stage were carried out in $500 \mathrm{~mL}$ polypropylene containers with $50 \mathrm{~mL}$ of culture medium, which were incubated at $26 \pm$ $1^{\circ} \mathrm{C}$ and a $16 \mathrm{~h}^{-1}$ light photoperiod.

\section{Stage 3. Rooting and acclimatization}

In the greenhouse of Saltillo Experimental Station of CIRNE-INIFAP were established vitro-plants of $10 \mathrm{~mm}$ high, through a completely randomized experimental design with a $4 \times 2$ factorial arrangement, with three replications per treatment. Factor $\mathrm{A}$ consisted of four kinds of substrates (S): $\mathrm{Sl}=$ =sand; S2= "peat moss"; S3 = black and S4= homogeneous mixture of the three mentioned before, and factor $B$ in the inoculation of Azospirillum brasilense in two concentrations: $\mathrm{CONCl}=1.5 \times 10^{6}$ and CONC 2 $=3 \times 10 \mathrm{UFC/} \mathrm{mL}^{-1}$. Also, a control was considered for each kind of substrate, without addition of the fungus. The additions of the fungus concentration were made every 7 days, assessing every 30 days; the variables were: stem height increment (SHI), root length (RL) and number of roots (NR).

The information of the stages was analyzed by means of the GLM procedure of the Statistics Analysis SAS (2002), by the mean comparison test, with a $95 \%$ probability for the significant treatment selection.

\section{RESULTS AND DISCUSSION}

\section{Stage 1. Seed establishment in an aseptic culture}

Germination per cent (GP). Significant differences were obtained from the $M B G \times C$, interaction with a positive effect in different proportions, when the germination stimulant was added, the al 50\% MBG2= MS treatment (Murashige and Skoog, 1962) + $8.65 \mathrm{mM}$ of $\mathrm{AG}_{3}$ which resulted in $75 \%$ of $\mathrm{GP}$, which doubled the emergence of the vitro-plants, in regard to the $\mathrm{MBGl}$ medium $=0.6 \%$ agar $+87.64 \mathrm{mM} \mathrm{C}_{22} \mathrm{H}_{22} \mathrm{O}_{11}+8.65 \mathrm{mM}$ de $A_{G}$. This shows that in in vitro, T. knuthianus demands nutriment and phytohormone addition to promote imbibition, oxygen absorption, enzymatic activation, hydrolized molecule transport up to meristematic apex and thus, to stimulate the respiration process, cell division and elongation for the growth of the vitro-plant.

With the osmotic potential present in the MBG4 medium $=0.6 \%$ agar $+87.64 \mathrm{mM}$ of $\mathrm{C}_{12} \mathrm{H}_{22} \mathrm{O}_{11}$ was determined a $10 \%$ of $P G$, which shows that the seed is viable, quiescent and its structure favors imbibition, tissue hydration and digestion, 
Con el potencial osmótico presente en el medio MBG4=0.6\% agar+87.64 mM de $\mathrm{C}_{22} \mathrm{H}_{22} \mathrm{O}_{11}$ se determinó un $\mathrm{PG}$ del $10 \%$, lo que muestra que la semilla es viable, quiescente y que su estructura permite la imbibición, hidratación de los tejidos y la digestión pero no así la translocación y división celular para la emergencia de la vitro-plántula.

De acuerdo con Maiti et al. (1994) especies con semillas de este tipo tienen una testa delgada y sólo requieren de condiciones ambientales favorables para que su germinación, ya que existe una fuerte relación entre la ultraestructura de la semilla y el proceso germinativo, en el cual influye el medio de cultivo que se utilice como lo refieren Dutra et al., 2008; Kauth et al., 2006 y Malda et al., 1999.

La modificación al medio de cultivo in vitro se ha realizado en otras cactáceas Mammillaria elongata DC., Selenicereus megalanthus (K. Schum. ex Vaupel) Moran y Hylocereus undatus (Haw.) Britton et Rose para favorecer el metabolismo celular de la semilla, activar el crecimiento del embrión y el proceso enzimático de los tegumentos, para que la cubierta de la semilla se rompa y emeria una nueva vitro-plántula (Papafotiou et al., 2001; Pelah et al., 2002) (Figura 2). but not translocation, and cell division for the emergence of the vitro-plant.

According to Maiti et al. (1994) species with seeds of this kind have a thin test and only demand favorable environmental conditions for their germination, since there is a strong relation between the ultrastructure of the seed and the germination process, in which the culture medium has an influence that is used as Dutra et al., 2008; Kauth et al., 2006 and Malda et al., 1999 refer.

The modification of the medium of the in vitro culture has been accomplished with other cacti Mammillaria elongata DC., Selenicereus megalanthus (K. Schum. ex Vaupell) Moran and Hylocereus undatus (Haw.) Britton et Rose to stimulate seed cell metabolism, to activate the growth of the embryo and the enzymatic process of teguments, so that the seed cover brakes and emerges a new vitro-plant (Papafotiou et al., 2001; Pelah et al., 2002) (Figure 2).

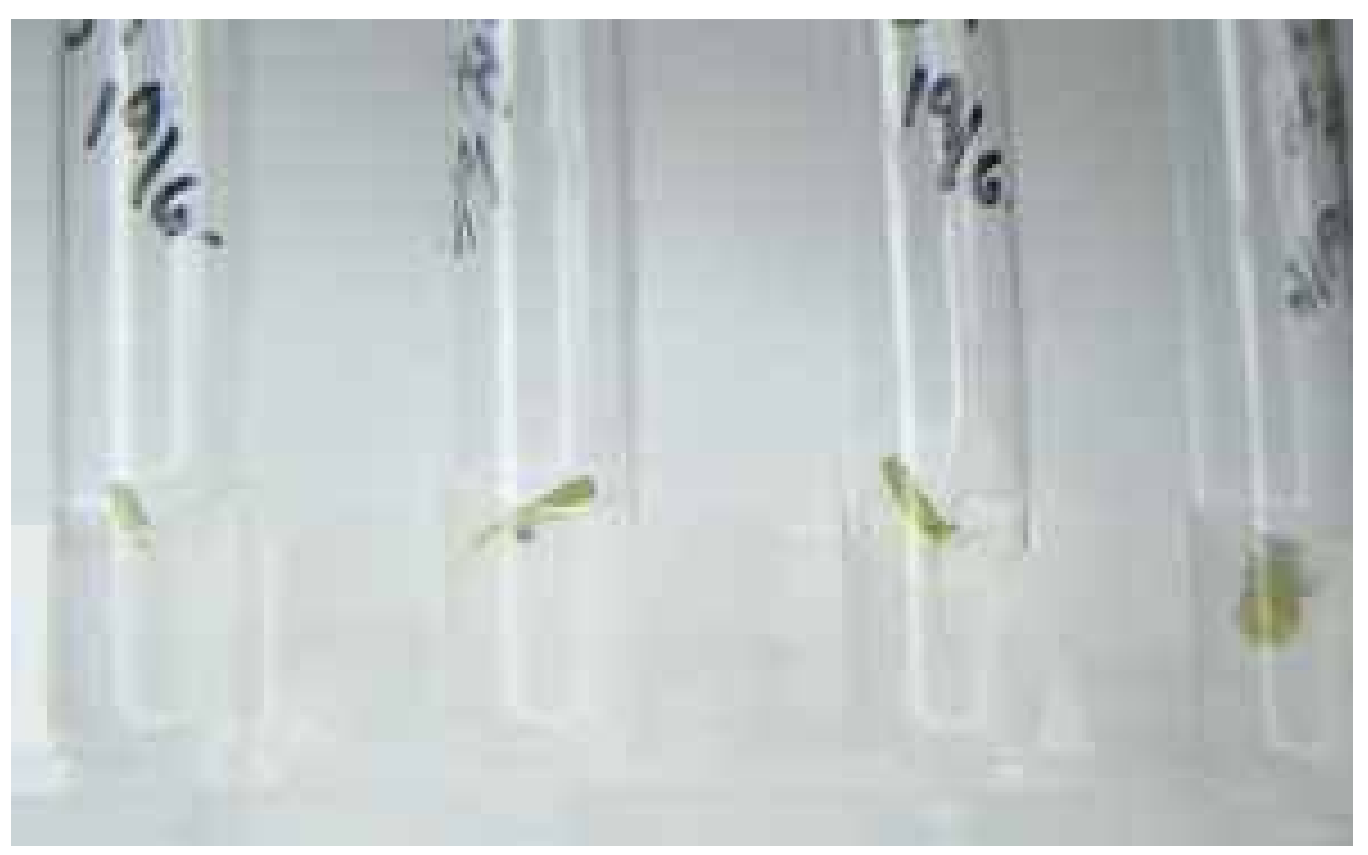

Figura 2. Establecimiento de semillas y aspecto de las plántulas de Turbinicarpus knuthianus después de 9 semanas de incubación.

Figure 2. Turbinicarpus knuthianus seed establishment and seedling looks after 9 weeks ofincubation. 
Velocidad de Germinación (VG)-- Durante los primeros 14 días de incubación no existieron diferencias significativas en el porcentaje de germinación registrado en los diferentes medios de cultivo (MBG). A partir de los 21 días el valor más alto se registró con el MBG T4, esta tendencia se mantuvo hasta el final del experimento. Se determinó que la velocidad de emergencia de T. knuthianus estuvo mediada por el medio de cultivo y por el ácido giberélico $\left(\mathrm{AG}_{3}\right)$, por lo que requiere de un promotor para la germinación, ya que los niveles endógenos de esta fitohormona no fueron suficientes para activar los procesos enzimáticos, como se mostró con los tratamientos sin fitohormona (T) y T2) (Figura 3). El mismo comportamiento también se ha observado en Astrophytum capricorne (A. Dietr.) Britton et Rose, otra cactácea del Desierto Chihuahuense, y en salvia (Salvia splendens Sellow ex Roem. et Shult.) para ésta última se ha estimado un $P G=87 \%$, con 100 y $150 \mathrm{mg} \mathrm{Ml}^{-1}$ de $A G 3$ y un $\mathrm{PG}=13 \%$, cuando no se adicionó el promotor al medio (De la Rosa-lbarra y García, 1994; De la Vega y Alizaga, 1987). Para Melocastus caesius H. L. Wendl., Stenocereus stellatus (Pfeiff.) Britton et Rose y otras especies de Mammillaria se ha observado que las giberelinas no promueven la germinación, si el proceso se realiza en la oscuridad (Araya et al., 2000; Rojas, 2008).
Germination Speed (GS).-During the first 14 days of incubation there were no significant differences in the germination per cent in the different culture media (MBG). From the 21 days, the highest value came from MBG T4, this tendency stayed as such till the end of the experiment. It was determined that the emergence speed of $T$. knuthianus was affected by the culture medium and the gibberellic acid $\left(\mathrm{AG}_{3}\right)$, which demands a germination stimulant, since the endogenous levels of this phytohormone were not enough to activate the enzymatic processes, as was shown by the treatments without phytohormone (T1 y T2) (Figure 3). The same behavior has been observed in Astrophytum capricorne (A. Dietr.) Britton et Rose, another cactus from the Chihuahuan Desert, and in Salvia splendens Sellow ex Roem. et Shult.; for the latter a GP of 87\% gas been estimated, with 100 y $150 \mathrm{mg} \mathrm{MH}^{-1}$ of $A G 3$ and a GP of $13 \%$ when the stimulant was not added to the medium (De la Rosa-lbarra and García, 1994; De la Vega and Alizaga, 1987). In Melocastus caesius H. L. Wendl., Stenocereus stellatus (Pfeiff.) Britton et Rose and other Mammillaria species it was observed that gibberellins do not promote germination if the process is made in the dark (Araya et al., 2000; Rojas, 2008).

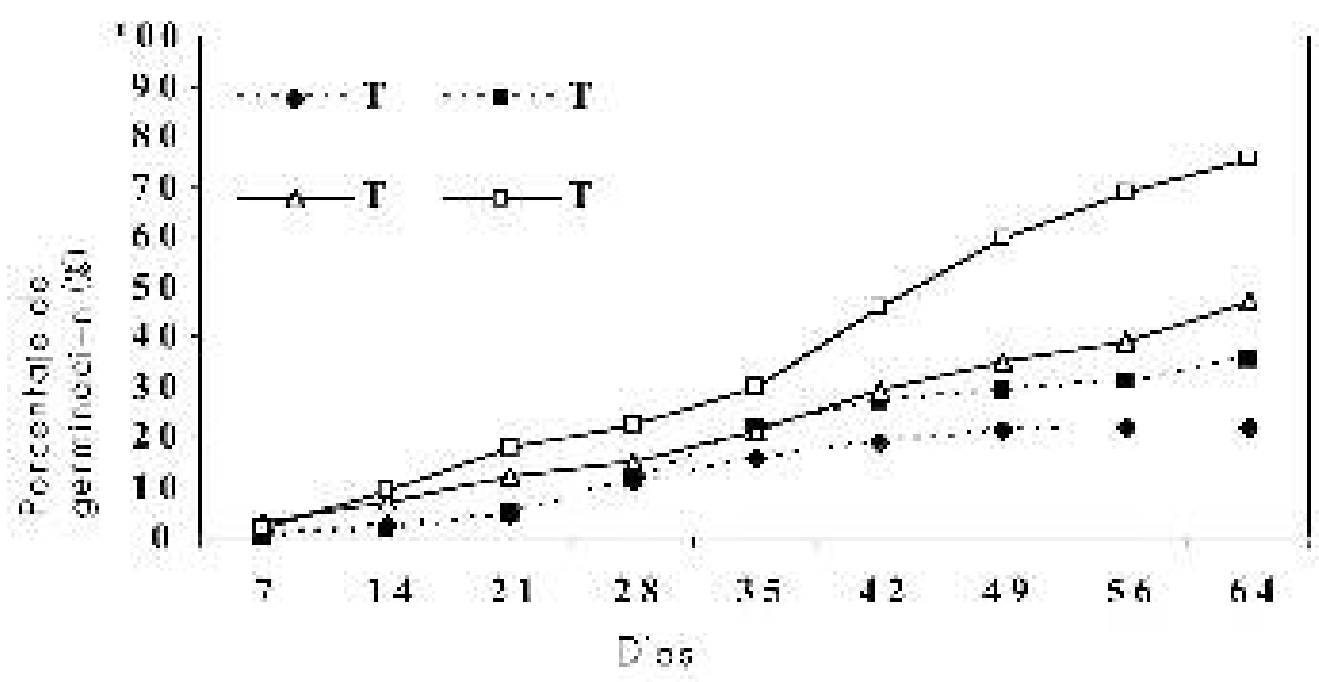

(T1 $=0.6 \%$ agar y $87.64 \mathrm{~m} \mathrm{M}$ de $\mathrm{C}_{12} \mathrm{H}_{22} \mathrm{O}_{11} ; \mathrm{T} 2=\mathrm{MS} 50 \%$; T3=0.6\% agar $+87.64 \mathrm{mM}$ de $\mathrm{C}_{12} \mathrm{H}_{22} \mathrm{O}_{11}+8.65 \mathrm{mM}$ de $\mathrm{AG}_{3}$; $\mathrm{T} 4=\mathrm{MS} 50 \%+8.65 \mathrm{mM}$ de $\mathrm{AG}_{3}$.

( $\mathrm{T}$ = $=0.6 \%$ agar and $87.64 \mathrm{~m} \mathrm{M}$ de $\mathrm{C}_{12} \mathrm{H}_{22} \mathrm{O}_{11} ; \mathrm{T} 2=\mathrm{MS} 50 \%$; T3=0.6\% agar $+87.64 \mathrm{mM}$ de $\mathrm{C}_{22} \mathrm{H}_{22} \mathrm{O}_{11}+8.65 \mathrm{~m} M$ de $A G_{3}$; T4= MS 50\%+8.65 mM de $\mathrm{AG}_{3}$.

Figura 3. Velocidad de germinación de Turbinicarpus knuthianus en diferentes medios de cultivo MBG Figure 3. Germination speed of Turbinicarpus knuthianus in different culture media. 


\section{Etapa 2. Multiplicación o inducción de brotes}

Existen diferencias significativas ( $P \leq 0.05)$ entre el tipo de fitohormonas (F) utilizadas para la inducción de brotes; con la cinetina (Kin) se obtuvo la mejor respuesta, con un NB promedio de 6.0 brotes por explante con una altura (A) de $6.0 \mathrm{~mm}$, a diferencia de los explantes establecidos en BA, los cuales registraron $30 \%$ menor cantidad de brotes con una altura de $5 \mathrm{~mm}$ en promedio (cuadros 2 y 3 ).
Stage 2. Shoot multiplication or induction

There are significant differences $(P \leq 0.05)$ among the type of phytohormones (F) used for the shoot induction; with kinetine (Kin) the best response was obtained, with an average NB of 6.0 shoots per explant of $6.0 \mathrm{~mm}$ high (A) which is different compared to those established in BA, which registered 30\% less number of shoots with an average height of $5 \mathrm{~mm}$ (Tables 2 and 3).

Cuadro 2. Significancia de las variables Número (NB) y Altura (AB) de brotes de Turbinicarpus knuthianus en la etapa de multiplicación en laboratorio.

Table 2. Significance of the Number (NB) and Height (AB) of Turbinicarpus knuthianus in the multiplication stage in the laboratory.

\begin{tabular}{lccc}
\hline \multicolumn{1}{c}{ F.V. } & g.l. & Número de Brotes & Altura de Brotes \\
\hline Fitohormona (F) & 1 & $*$ & $* *$ \\
Concentracion (C) & 5 & $* *$ & $* *$ \\
FxC & 4 & $* *$ & $\mathrm{NS}$ \\
FxCXR & 25 & $* *$ & \\
Error & & 5173 & 4863 \\
$r^{2}$ & & 0.53 & 0.29 \\
CV & 23.61 & 21.12 \\
media & 4.43 & 5.40 \\
\hline
\end{tabular}

F.V. = fuente de variación; g.l. = grados de libertad; NS= No significativo; ${ }^{*}=$ significativo (a $\alpha \leq 0.05$ ), ${ }^{* *}=$ altamente significativo (a $\alpha \leq 0.01$ ); R= Repetición. F.V. = source of variation; g.l. = degrees of freedom; NS= Non significant; ${ }^{*}=$ significant (a $\alpha \leq 0.05$ ), ${ }^{* *}=$ highly significant (a $\alpha \leq 0.01$ ); R= Replication.

Cuadro 3. Influencia de las fitohormonas en el Número (NB) y Altura (AB) de brotes de Turbinicrpus knuthianus en laboratorio. Table 3. Influence of phytohormones on the Number (NB) and Height (AB) of shoots of Turbinicarpus knuthianus in the laboratory.

\begin{tabular}{|c|c|c|}
\hline Fitohormona & Número de Brotes & Altura (mm) \\
\hline Kin & $5.87 a$ & $5.91 \mathrm{~b}$ \\
\hline BA & $3.87 b$ & $5.18 b$ \\
\hline Sin Fitohormona & $2.33 c$ & $8.22 a$ \\
\hline CME & 3.74 & 4.93 \\
\hline DMS & 1.23 & 1.42 \\
\hline$r^{2}$ & 0.71 & 0.65 \\
\hline $\mathrm{CV}$ & 23.61 & 21.12 \\
\hline Media & 4.43 & 5.40 \\
\hline
\end{tabular}

Kin = Cinetina; $B A=$ Bencilaminopurina

CME= Cuadrado medio del error; DMS= Diferencia minima significativa; CV= Coeficiente de variación.

Valores con la misma letra dentro de columnas no difieren significativamente (Tukey $P \leq 0.05$ ).

Kin = Kinetine; $\mathrm{BA}=$ Bencilaminopurine

MSE= Mean Square Error; MSD= Minimum Significant Difference; $C V=$ Coefficient of variation

Values with the same letter in the columns have not significant differences (Tukey $P \leq 0.05$ ). 
Al comparar este efecto con el tratamiento sin fitohormonas se comprobó que de forma endógena $T$. knuthianus es capaz de producir brotes; sin embargo, su regeneración es baja (2.33 brotes por explante) (Cuadro 3).

Después de analizar los tratamientos como efectos independientes con la prueba de medias ( $P \leq 0.05$ ), se determinó que el tratamiento T12 tiene un efecto positivo en la inducción de brotes, hasta 10 brotes por explante en el medio MIB adicionado con $4.40 \mathrm{mM}$ de BA + $4.13 \times \mu \mathrm{M}$ de AIB. Lo anterior contrasta con el tratamiento $T 2$, en el cual se obtuvieron 9 brotes por explante en un $M I B$ con una baja concentración de Kin 0.46 mM de Kin + $0.61 \mu$ M de ABB. Los resultados muestran que la concentración de citosina-auxina en una relación 10:1 es positiva para la inducción de brotes; aunque su efecto depende del tipo de fitohormona que se utilice. A diferencia de lo sucedido con el tratamiento sin fitohormona, en el que se tuvo el menor número de brotes.

La interacción citosina-auxina ha sido efectiva en la organogénesis directa de 21 especies de cactáceas mexicanas, como lo refieren Pérez et al. (1998) y Mata et al. (2001), entre ellas las del género Turbinicarpus, cuando se utilizaron de 8.8-13.31 mM de BA y 0-2.6 $\mu$ M de ANA en medio de cultivo MS (Murashige y Skoog, 1962).

Altura de brotes (A). Se registraron diferencias significativas entre los tratamientos con y sin fitohormona, éste último presentó la mayor altura de brotes $(8.22 \mathrm{~mm})$, a diferencia de los tratamientos con fitohormonas, mismos que registraron un valor estadísticamente igual a $6 \mathrm{~mm}$, cuando se utilizo cinetina (KIN) (Cuadro 4, Figura 4).

Al analizar el efecto del tipo de fitohormona se observó que la altura de los brotes se reduce al aumentar su número de explantes, como sucedió en los tratamientos T2 y T12, con 4 y $3 \mathrm{~mm}$, respectivamente (Cuadro 4).

Un efecto opuesto se obtuvo cuando se utilizó BA, en los que el número y altura de los brotes se incrementa conforme se aumenta la concentración de la citocinina, de tal manera que con la concentración entre 0.66 a $3.3 \mathrm{mM}$ de $\mathrm{BA}$ el número máximo de brotes por explante fue de cuatro con una altura superior a $5 \mathrm{~mm}$; sin embargo, con la concentración más alta (4.40 mM de BA), la tasa de multiplicación es más del doble, pero los brotes son de menor tamaño ( $3 \mathrm{~mm}$ en promedio) (Cuadro 4). Algo similar se presentó en Mammillaria sanangelensis Sánchez-Mej., cuando se utilizó una concentración alta de fitohormona $(4.4 \mathrm{mM}$ de BAP + $0.53 \mu \mathrm{M}$ de ANA), la cual indujo la generación de 21 brotes por explante, con una altura menor a $3 \mathrm{~mm}$ (Martínez-Vázquez y Rubluo, 1989).
When this effect was compared to the treatment without phytohormones, it was probed that in an endogeneous form, T. kurbinicarpus can produce shoots; however, its regeneration is low (2.33 shoots per explants) (Table 3).

After analyzing the treatments as independent effects by the mean test ( $P \leq 0.05$ ), it was determined that the T12 treatment has a positive incidence in shoot induction, up to 10 shoots per explant in a MB medium added with $4.40 \mathrm{mM}$ of $B A+4.13 \times$ $\mu \mathrm{M}$ of $\mathrm{AB}$. The former contrasts with the $\mathrm{T} 2$ treatment in which 9 shoots per explant were obtained in a MBB with low concentration of $\mathrm{Kin} 0.46 \mathrm{mM}$ of $\mathrm{Kin}+0.67 \mu \mathrm{M}$ of $\mathrm{AB}$. Results show that the 10: 1 kitosine-auxine relation is positive for shoot induction, even if its reaction depends on the type of phytohormone that is used, which is different from what happened with the treatment without phytohormone, in which the least number of shoots was produced.

The kitosine-auxine interaction has been effective in direct organogenesis of 21 species of Mexican cacti as Pérez et al. (1998) and Mata et al. (2001) refer, among them those of Turbinicarpus genus, when 8.8- $13.31 \mathrm{mM}$ of BA and 0-2.6 $\mu \mathrm{M}$ of ANA in MS (Murashige and Skoog, 1962) culture medium were used.

Shoot height (A). Significant differences were found among treatments with and without phytohormones, the latter having recorded a greater shoot height $(8.22 \mathrm{~mm})$, in contrast to the treatments with phytohormones, which recorded a value statistically equal to $6 \mathrm{~mm}$, when kinetine (KIN) was used (Table 4, Figure 4).

When analyzing the effect of the phytohormone type it was observed that the height of the shoots is reduced when the number of explants increases, as it happened with $\mathrm{T} 2$ and $\mathrm{T} 12$ treatments, which produced 4 and $3 \mathrm{~mm}$ (Table 4 ).

The opposite effect was obtained when BA was used: the number and height of the shoots increases as the kitocinine concentration does, in such a way that with the 0.66 to $3.3 \mathrm{mM}$ of $\mathrm{BA}$ concentration the maximum number of shoots per explant was 4 with a height over $5 \mathrm{~mm}$; however, with the highest concentration (4.40 mM of BA), the multiplication rate becomes more than twice, but shoots are smaller in size ( $3 \mathrm{~mm}$ average) (Table 4). Something similar happened with Mammillaria sanangelensis Sánchez-Mej. when a high concentration of phytohormone (4.4 mM of BAP + $0.53 \mu \mathrm{M}$ of ANA) was used, which induced the generation of 21 shoots per explant, with a height lower than $3 \mathrm{~mm}$ (Martínez-Vázquez and Rubluo, 1989). 
Cuadro 4. Tasa de multiplicación de Turbinicarpus knuthianus (Boed.) John \& Riha.

Table 4. Multiplication rate of Turbinicarpus knuthianus (Boed.) John \& Riha.

\begin{tabular}{|c|c|c|c|c|c|}
\hline \multirow{3}{*}{ TRATAMIENTOS } & \multicolumn{3}{|c|}{ Concentración ( $\mu M)$} & \multirow{3}{*}{ NB } & \multirow{3}{*}{$A$} \\
\hline & \multicolumn{2}{|c|}{$\mathrm{m} M$} & \multirow{2}{*}{$\frac{(\mu \mathrm{M})}{A B}$} & & \\
\hline & $\mathrm{KIN}$ & BA & & & \\
\hline 0 & 0 & 0 & 0 & $2.33 \mathrm{~h}$ & $8.22 a$ \\
\hline 1 & 0.46 & & 0.041 & $6.77 \mathrm{c}$ & $5.70 \mathrm{ab}$ \\
\hline 2 & 0.69 & & 0.061 & $8.66 b$ & $4.64 \mathrm{~b}$ \\
\hline 3 & 1.16 & & 0.103 & $6.24 \mathrm{~cd}$ & $4.74 b$ \\
\hline 4 & 2.32 & & 0.207 & $5.77 \mathrm{cde}$ & $6.54 \mathrm{ab}$ \\
\hline 5 & 3.48 & & 0.310 & 5.04 def & $6.97 \mathrm{ab}$ \\
\hline 6 & 4.64 & & 0.413 & 5.37 cdef & $6.49 \mathrm{ab}$ \\
\hline 7 & & 0.44 & 0.041 & $3.86 \mathrm{hg}$ & $6.82 \mathrm{ab}$ \\
\hline 8 & & 0.66 & 0.061 & $3.36 \mathrm{hg}$ & $4.55 b$ \\
\hline 9 & & 1.10 & 0.103 & $3.4 \mathrm{hg}$ & $4.92 b$ \\
\hline 10 & & 2.21 & 0.207 & $4.29 \mathrm{fge}$ & $5.34 \mathrm{ab}$ \\
\hline 11 & & 3.30 & 0.310 & $3.9 \mathrm{fg}$ & $6.09 \mathrm{ab}$ \\
\hline \multirow[t]{5}{*}{12} & & 4.40 & 0.413 & $10.87 a$ & $3.35 c$ \\
\hline & & & DMS & 1.23 & 1.10 \\
\hline & & & $r^{2}$ & 0.53 & 0.29 \\
\hline & & & CV & 23.61 & 21.12 \\
\hline & & & media & 4.43 & 5.40 \\
\hline
\end{tabular}

Valores con la misma letra dentro de columnas no difieren significativamente (Tukey $P \leq 0.05$ ).

$\mathrm{NB}=$ Número de brotes; $A=$ =Altura

Values with the same letter in the columns have not significant differences (Tukey $P \leq 0.05$ ).

$N B=$ Number of shoots; $A=$ Height

Con base en los resultados aquí documentados se puede decir que el control hormonal influye en la diferenciación del explante como lo refieren Mauseth (1976, 1979), y se demuestra que la regeneración de brotes in vitro de T. knuthianus es posible inducirla a partir de yemas axilares; así mismo, la eficiencia del método de propagación se expresa en el número de brotes por explante (Vyskot y Jara, 1984; Martínez-Vázquez y Rubluo, 1989; Clayton et al., 1990 y Dabekaussen et al., 1991).

También se determinó que la micropropagación de T. knuthianus ocurre si al medio de cultivo (MIB) se le agregan fitohormonas, ya que sus yemas axilares presentan letargo, con meristemos axilares quiescentes con potencial mitótico activo en cada una de sus zonas (a) célula madre central; b) zona periférica y c) meristemo), en donde es posible desarrollar primordios fotosintéticamente normales, llamados brotes, tal como lo describió Mauseth (1976, 1978, 1979), quien fue el primero en evaluar este efecto en cactáceas.
Based upon the results here supported, it can be stated that hormonal control influences the explant differentiation, as Mauseth $(1976,1979)$ refer and it is proved that T. knuthianus shoot regeneration in vitro can be induced from auxiliary buds; also, the efficiency of the propagation method is expressed in the number of shoots per explant (Vyskot and Jara, 1984; Martínez-Vázquez and Rubluo, 1989; Clayton et al., 1990; Dabekaussen et al., 1991).

It was also determined that the micropropagation of T. knuthanus occurs if phytohormones are added to the culture medium (MB), since their axillary buds show lethargy with quiescent axillary meristems that have active mitotic potential in each of their zones a) central mother cells, b) peripheric zone and c) meristem), in which it is possible to develop photosynthetically normal primordial structures known as shoots, as Mauseth (1976, 1978, 1979) described, being the first one to assess this effect on cacti. 


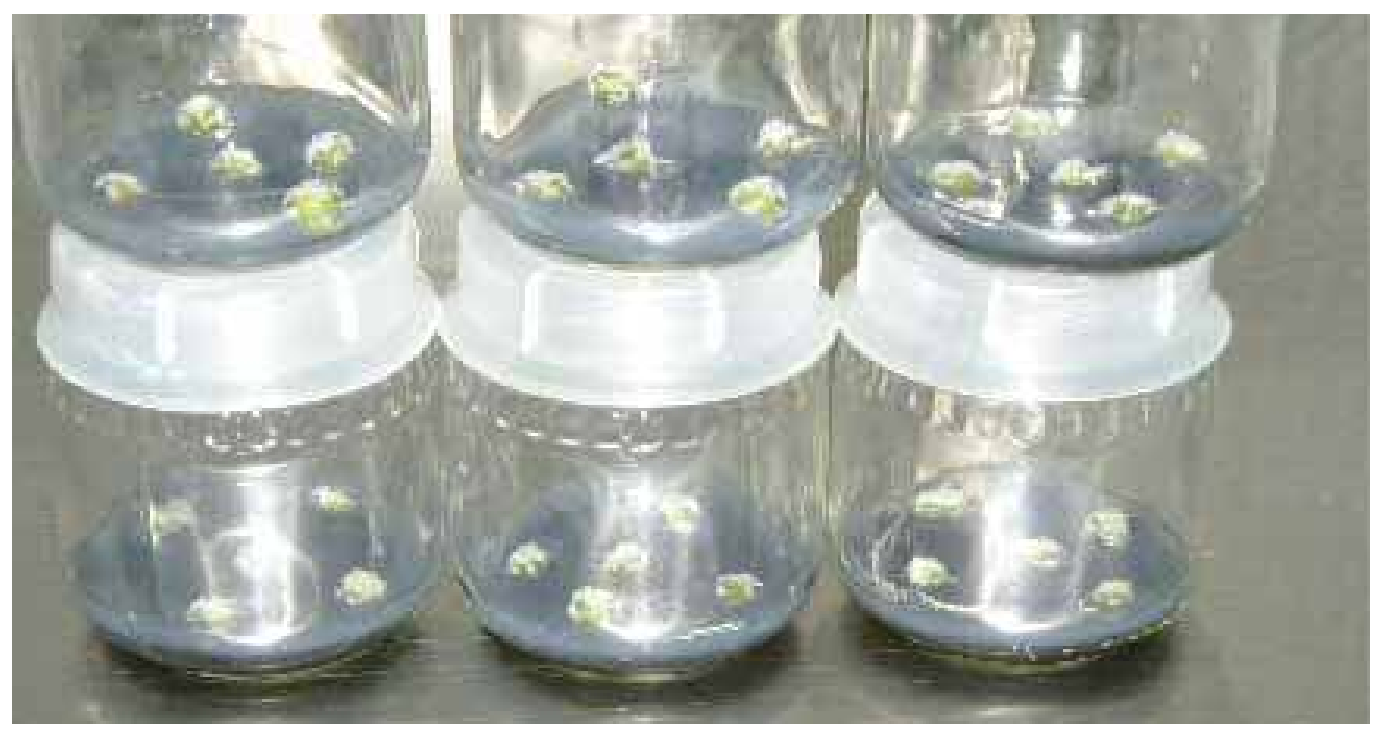

Figura 4. Brotes de Turbinicarpus knuthianus (Boed.) John \& Riha obtenidos en la etapa de multiplicación. Figure 4. Turbinicarpus knuthianus (Boed.) John \& Rihashoots produced in the multiplication stage.

La tasa de multiplicación de T. knuthianus es exponencial y varía dependiendo de la fitohormona que se utilice, siempre que se mantenga una relación 1:8:8:8; del medio de cultivo (MBB) adicionado con $0.69 \mathrm{mM}$ de $\mathrm{Kin}+0.67 \mu \mathrm{M}$ de $\mathrm{AIB}$. Los valores para esta variable fueron superiores al citado por Dávila et al. (2005) y Clayton et al. (1990) en Escobaria missouriensis (Sweet) D.R. Hunt, Pediocactus paradinei B. W. Benson y Toumeya papyracantha (Engelm) Britton et Rose, cuya tasa de multiplicación máxima fue de 6.0 brotes por explante.

En el caso de la cactácea estudiada la máxima tasa de multiplicación en relación de 1: 10: 10: 10 se obtiene in vitro en un medio de cultivo MIB con $4.4 \mathrm{mM}$ de BA+ $0.413 \mu \mathrm{M}$ (relación 1: 10: 10: 10). Esta cifra es semejante a la que se ha registrado en especies de los géneros: Coryphantha, Echinocereus y Mammillaria (Clayton et al., 1990) y en Astrophytum myriostigma Lem. (Villavicencio et al., 2006; 2009)., pero que supera a la consignada en otras especies de cactáceas mexicanas como Mammillaria voburnensis Scheer y Mammillaria elongata DC. (Ordóñez, 2003; Papafotiou et al., 2001).

\section{Etapa 3 enraizamiento y aclimatación}

En invernaderos donde se producen plantas ornamentales se utiliza una gran variedad de materiales de tipo orgánico e inorgánico, como sustratos solos o mezclados que proveen un medio para el crecimiento de la planta como: tezontle fino, "tepojal" (roca volcánica extrusiva de textura vesicular, burbujeada y porosa que guarda el calor), polvillo de coco, perlita, arena, tierra de hoja molida, "peat moss", vermiculita, bagazo de caña de azúcar molido, cascarilla de arroz y aserrín entre otros.
The multiplication rate of $T$. knuthianus is exponential and varies according to the phytohormone that is used, in so far as is kept a 1:8:8:8 relation of the culture medium (MIB) to which is added $0.69 \mathrm{mM}$ of $\mathrm{Kin}+0.61 \mu \mathrm{M}$ of $\mathrm{AB}$. The values for this variable were higher than those of Dávila et al. (2005) and Clayton et al. (1990) for Escobaria missouriensis (Sweet) D.R. Hunt, Pediocactus paradinei B. W. Benson and Toumeya papyracantha (Engelm) Britton et Rose, whose maximum multiplication rate was 6.0 shoots per explant.

In the case of the studied cactus, the maximum multiplication rate in a 1:10:10: 10 relation results from an in vitro essay in a MBB culture medium (1:10: 10: 10 relation). This number is similar to what is recorded in species of the genus Coryphantha, Echinocereus and Mammillaria (Clayton et al., 1990) and in Astrophytum myriostigma Lem. (Villavicencio et al., 2006; 2009), but that is over that recorded for other species of Mexican cacti such as Mammillaria voburnensis Scheer and Mammillaria elongata DC. (Ordóñez, 2003; Papafotiou, et al., 2001 ).

\section{Stage 3. Rooting and acclimatization}

In greenhouses when ornamental plants are produced a great variety of organic and inorganic materials is used, as simple or mixed substrata that provide the medium for plant growth such as fine "tezontle", "tepojal" (extrusive volcanic rock of vesicular texture, bubbled and porous that keeps heat), coconut dust, clinkstone, sand, mashed leaf-soil, "peat moss", vermiculite, mashed sugar cane bagasse, rice husk and sawdust.

Stem height increment $(\mathrm{SH})$. In the three first dates of application were determined highly significant differences 
Incremento en altura del tallo (IAT). En las tres primeras fechas de aplicación se determinaron diferencias altamente significativas $(P \leq 0.05)$ entre los efectos independientes $S$ y CONC, de tal manera que, al final de la evaluación, el IAT fue estadísticamente igual en los tres primeros sustratos evaluados $(S 1=$ arena, $S 2=$ peat moss y $\mathrm{S} 3=$ negra $)$, con un IAT de $17 \mathrm{~mm}$, superior al de las plantas aclimatadas en el sustrato S4. Se obtuvo un efecto positivo con la interacción SxCONC, cuando se inoculó la cepa de Azospirillum brasilense en baja concentración (CONCl=1.5x10 $\mathrm{UFCl} \mathrm{ml}-1)$, y los tres sustratos referidos superan en IAT al resto de los tratamientos. Al final del proceso de aclimatación se tuvieron plantas entre 4 y $7 \mathrm{~cm}$ de altura con un $95 \%$ de sobrevivencia; con ello se demuestra que la concentración de unidades formadoras de colonias (UFC) influye positivamente en el aumento de IAT, a diferencia de sus homólogos, los testigo, en donde los que los IAT resultaron estadísticamente igual y menor a $2 \mathrm{~mm}$ (cuadros 5 y 6 ).
( $P \leq 0.05$ ) between the independent $S$ effects and the CONC, in such a way that, at the end of the assessment, the SHI was statistically equal in the three first evaluated substrates (S1=sand, S2= peat moss and S3= black) with a SH = $17 \mathrm{~mm}$, which is higher to the acclimatated plants in substrate S4. A positive effect with the SxCONC interaction was obtained when the Azospirillum brasilense in a low concentration $\left(\mathrm{CONCl}=1.5 \times 10^{6} \mathrm{UFCl} \mathrm{ml}-1\right)$, was inoculated and the three referred substrata surpass the $\mathrm{SH}$ of the rest of the treatments. At the end of the acclimatization process plants were between 4 and $7 \mathrm{~cm}$ high with a $95 \%$ survival; thus, it is probed that the concentration of colony-forming units (CFU) has a positive influence upon the increment of $\mathrm{SH}$, compared to their homologous, the controls, in which SHI were statistically equal or below $2 \mathrm{~mm}$ (Tables 5 and 6 ).

Cuadro 5. Significancia de las variables Incremento en altura de tallo, longitud de raíz y número de raíces evaluadas en el enraizamiento de Turbinicarpus knuthianus en invernadero.

Table 5. Significance of the stem height increment, root length and number of assessed roots in the rooting of Turbinicarpus knuthianus at the greenhouse.

\begin{tabular}{lcccc}
\hline \multicolumn{1}{c}{ F. V. } & gl & IAT & NR & LR \\
\hline Sustrato (S) & 3 & $* *$ & $* *$ & $* *$ \\
Concentración cepa (CON) & 2 & $* *$ & $* *$ & \\
REP & 2 & & & \\
SxCONC & 6 & $* *$ & $* *$ & \\
SxCONCXREP & 22 & $* *$ & & $* *$ \\
Error & 324 & & & \\
Total & 359 & & & \\
$r^{2}$ & & 0.65 & 0.66 & 60.42 \\
CV (\%) & & 21.82 & 27.41 & 15.19 \\
Media & & 1.1 & 3.96 & 2.30 \\
\hline
\end{tabular}

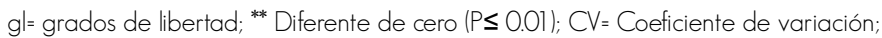
$\mid A T$ = incremento en altura de tallo; $N R$ = número de raíces; $L R=$ longitud de raíz. $\mathrm{gl}=$ degrees of freedom; ${ }^{* *}$ Different from cero $(\mathrm{P} \leq \mathrm{0.01}) ; \mathrm{CV}=$ Coefficient of variation: $I A T=$ increment of stem height; $N R=$ number of roots; $L R=$ root length 
Cuadro 6. Influencia del sustrato en el incremento de atura de tallo, longitud de raíz y número de raíces durante la aclimatación de Turbinicarpus knuthianus.

Table 6. Influence of substrate upon stem height increment, root length and number of roots during the acclimatization of Turbinicarpus knuthianus.

\begin{tabular}{lccc}
\hline \multirow{2}{*}{ Sustrato } & IAT & \multicolumn{1}{c}{ LR } & \multirow{2}{*}{ NR } \\
\cline { 2 - 3 } & (cm) & (cm) & \\
\hline S1 & $1.25 a$ & $2.97 a$ & $4.32 a$ \\
S2 & $1.12 a$ & $2.15 b c$ & $4.12 a$ \\
S3 & $1.19 a$ & $2.35 b$ & $4.24 a$ \\
S4 & $0.88 b$ & $1.75 c$ & $3.16 b$ \\
DMS & 0.22 & 0.41 & 0.41 \\
\hline
\end{tabular}

Medias con letras iguales entre columnas, no son estadísticamente diferentes (Tukey, 0.05).

$\mid A T=$ incremento en altura de tallo; $N R=$ número de raíces; $L R=$ longitud de raíz; $S 1$ =arena, $S 2=$ "peat moss", $S 3=$ negra $y$ S4= mezcla homogénea de las tres anteriores; DMS = Diferencia mínima significativa.

Means with the same letters between columns, are not statistically different (Tukey, 0.05).

$I A T=$ stem height increment; $N R=$ number of roots; $L R=$ root length; $\mathrm{S} 1=$ sand, S2= "peat moss", S3= black and S4= homogeneous mixture of the three mentioned before; DMS = Least significant difference.

Número de raíces (NR). Se obtuvo un efecto igual al descrito para el IAT con los tres sustratos usados. En promedio 4 raíces por planta, con la misma concentración de unidades formadoras de colonias (UFC) (cuadros 5 y 6). Los resultados duplican en NR a los observados con sus tratamientos homólogos, pero sin la aplicación de la cepa, lo que muestra que T. knuthianus tiene niveles endógenos de auxinas que le permiten inducir el proceso rizogénico, como lo citado para Capsicum chinese Jacquin, con una concentración similar (CONCl $=1.5 \times 10^{6} \mathrm{UFC}^{-1}$ ) (Canto et al., 2004) (Cuadro 7); sin embargo son relativamente bajos comparados con los de otras especies (Camellia sinensis (L.) Kuntze) según Tomasz et al. (2006).

Al analizar los tratamientos como efectos independientes, el tratamiento T2 en la prueba de medias (Tukey $\infty 0.05$ ) resultó significativo, con un valor máximo de 6 raíces por planta, mientras que $\mathrm{Tl}$ y $\mathrm{T} 3$ fueron estadísticamente iguales con 5 raíces por planta, y duplican el número de raíces, con respecto a los tratamientos homólogos sin la aplicación de la cepa, cuyo número de raíces no fue mayor a 2 por planta, lo que confirma que la especie tiene niveles endógenos de auxinas (Canto et al., 2004) (Cuadro 8, Figura 5).
Cuadro 7. Influencia de la concentración de las unidades formadoras de colonias de Azospirillum brasilense en el incremento de altura del tallo, longitud de raíz y número de raíces durante la aclimatación de Turbinicarpus knuthianus.

Table 7. Influence of Azospirillum brasilense concentration of colony-forming units (CFU) upon stem height increment, root length and number of roots during the acclimatization of Turbinicarpus knuthianus.

\begin{tabular}{cccc}
\hline & IAT & \multicolumn{1}{c}{$L R$} & \multirow{2}{*}{ NR } \\
\cline { 2 - 3 } Concentración & $(\mathrm{cm})$ & $(\mathrm{cm})$ & \\
\hline 0 & $0.28 \mathrm{c}$ & $2.45 \mathrm{a}$ & $2.16 \mathrm{~b}$ \\
1 & $1.63 \mathrm{a}$ & $2.21 \mathrm{a}$ & $4.92 \mathrm{a}$ \\
2 & $1.42 \mathrm{~b}$ & $2.25 \mathrm{a}$ & $4.80 \mathrm{a}$ \\
DMS & 0.17 & 0.42 & 0.33 \\
\hline
\end{tabular}

Medias con letras iguales entre columnas, no son estadísticamente diferentes (Tukey, 0.05).

$\mathrm{CONCl}=1.5 \times 10^{\circ}$ y $\mathrm{CONC} 2=3 \times 10 \mathrm{UFCl} \mathrm{ml}-1$ de $\mathrm{A}$. brasilense; $\mathrm{IAT}=$ incremento en altura de tallo; $N R$ = número de raíces; $L R=$ longitud de raíz; $D M S$ = Diferencia mínima significativa.

Means with the same letters between columns, are not statistically different (Tukey, 0.05).

$\mathrm{CONCl}=1.5 \times 10^{6}$ and $\mathrm{CONC} 2=3 \times 10^{\circ} \mathrm{UFC} / \mathrm{ml}-1$ of $\mathrm{A}$. brasilense; $\mid \mathrm{AT}=$ stem height increment; $N R=$ number of roots; $L R=$ root length; $D M S$ = Least significant difference.

Number of roots (NR). The same effect to that described for the IAT was obtained with the three substrates that were used. Four roots per plant in average, with the same concentration of colony-forming units (CFU) (Tables 5 and 6). These results duplicate the NR observed in the homologous treatments, but without the bacteria, which shows that $T$. knuthianus has endogenous levels of auxines that helps in the rhizogenic process as has been reported for Capsicum chinese Jacquin, with a similar concentration $\left(\mathrm{CONCl}=1.5 \times 10^{6}\right.$ UFC $\left.\mathrm{ml}^{-1}\right)$ (Canto et al., 2004) (Table 7); however, they are rather low compared to other species (Camellia sinensis (L.) Kuntze) according to Tomasz et al. (2006).

While analyzing the treatments as independent events, T2 treatment in the mean test (Tukey $\infty 0.05$ ) was significant, with a maximum value of 6 roots per plant, while $T i$ and $T 3$ were statistically the same with 5 roots per plant, and doubled the number of roots in regard to the homologous treatments without the bacterium, whose number of roots was not over 2 per plant, which confirms that the species has endogenous levels of auxines (Canto et al., 2004) (Table 8, Figure 5). 
Cuadro 8. Comparación de medias de los tratamientos evaluados en el enraizamiento y aclimatación de Turbinicarpus knuthianus. Table 8. Comparison of the means of the assessed treatments of rooting and acclimatization of Turbinicarpus knuthianus.

\begin{tabular}{|c|c|c|c|c|c|c|}
\hline & \multirow{2}{*}{ Tratamientos } & IAT & $L R$ & \multirow{2}{*}{ NR } & AFP & \multirow{2}{*}{$\begin{array}{c}\text { Supervivencia } \\
(\%)\end{array}$} \\
\hline & & $(\mathrm{cm})$ & $(\mathrm{cm})$ & & $(\mathrm{cm})$ & \\
\hline $\mathrm{Tl}$ & Arena $+1.5 \times 10^{6} \mathrm{UFC} / \mathrm{ml}-1$ cepa & $1.73 \mathrm{ab}$ & $2.67 a$ & $5.20 \mathrm{~b}$ & $4.28 \mathrm{ab}$ & $90 \mathrm{~b}$ \\
\hline $\mathrm{T} 2$ & Peat moss $+1.5 \times 10^{6} \mathrm{UFC} / \mathrm{ml}-1$ cepa & 2.09 a & $2.50 \mathrm{ab}$ & $5.90 \mathrm{a}$ & $7.6 a$ & 100 a \\
\hline T3 & Tierra de monte $+1.5 \times 10^{6} \mathrm{UFC} / \mathrm{ml}-1 \mathrm{cepa}$ & $1.88 \mathrm{ab}$ & $2.25 \mathrm{~cd}$ & $5.20 \mathrm{~b}$ & $5.35 \mathrm{ab}$ & $100 \mathrm{a}$ \\
\hline T4 & Mezcla de sustratos + $1.5 \times 10^{6} \mathrm{UFC/} \mathrm{ml-} 1$ cepa & $0.82 \mathrm{de}$ & $1.42 \mathrm{f}$ & 3.40 e & $2.71 \mathrm{c}$ & $90 \mathrm{~b}$ \\
\hline T5 & Arena + 3x10 UFC/ ml- 1 cepa & $1.46 \mathrm{bc}$ & $2.45 b c$ & $5.26 b$ & 6.46 a & $90 \mathrm{~b}$ \\
\hline T6 & Peat moss + 3x10 UFC/ ml- 1 cepa & $1.19 \mathrm{~cd}$ & 1.94 e & $4.60 c$ & $2.97 c$ & $90 \mathrm{~b}$ \\
\hline ד & Tierra de monte + 3x10 UFC/ ml- 1 cepa & $1.48 \mathrm{bc}$ & $2.53 \mathrm{ab}$ & $5.33 b$ & $4.69 \mathrm{ab}$ & $80 c$ \\
\hline T8 & Mezcla de sustratos + 3x10 UFC/ ml- 1 cepa & $1.56 b c$ & $2.06 \mathrm{de}$ & $4.00 \mathrm{~d}$ & $2.4 \mathrm{~cd}$ & $90 \mathrm{~b}$ \\
\hline T9 & Arena + Fertilización (Testigo) & 0.55 ef & $1.76 \mathrm{~cd}$ & $2.50 \mathrm{f}$ & $2.35 \mathrm{~cd}$ & $80 c$ \\
\hline $\mathrm{T} 10$ & Peat moss + Fertilización I (Testigo) & $0.09 \mathrm{f}$ & $1.42 \mathrm{f}$ & $1.86 \mathrm{~g}$ & $1.8 d$ & $60 c$ \\
\hline $\mathrm{T} 11$ & Tierra de monte + Fertilización (Testigo) & $0.20 \mathrm{f}$ & $1.36 \mathrm{~g}$ & $2.20 \mathrm{fg}$ & $1.5 d$ & $70 c$ \\
\hline \multirow[t]{4}{*}{$\mathrm{T} 12$} & Mezcla de sustratos + Fertilización (Testigo) & $0.28 \mathrm{f}$ & $1.34 \mathrm{~g}$ & $2.10 \mathrm{fg}$ & $1.25 \mathrm{e}$ & \multirow[t]{2}{*}{$80 c$} \\
\hline & DMS & 0.52 & 0.15 & 0.34 & 4.28 & \\
\hline & Media & 1.11 & 1.97 & 3.96 & 3.61 & 85 \\
\hline & CV & 19.27 & 10.34 & 13.18 & 5.35 & \\
\hline
\end{tabular}

Medias con letras iguales entre columnas, no son estadísticamente diferentes (Tukey, 0.05). IAT = incremento en altura de tallo; $N R=$ número de raíces; $L R=$ longitud de raíz; AFP = Altura final de la planta.

Means with the same letters between columns, are not statistically different (Tukey, 0.05). IAT = stem height increment; NR = number of roots; $L R=$ root length; AFP = Final plant height.

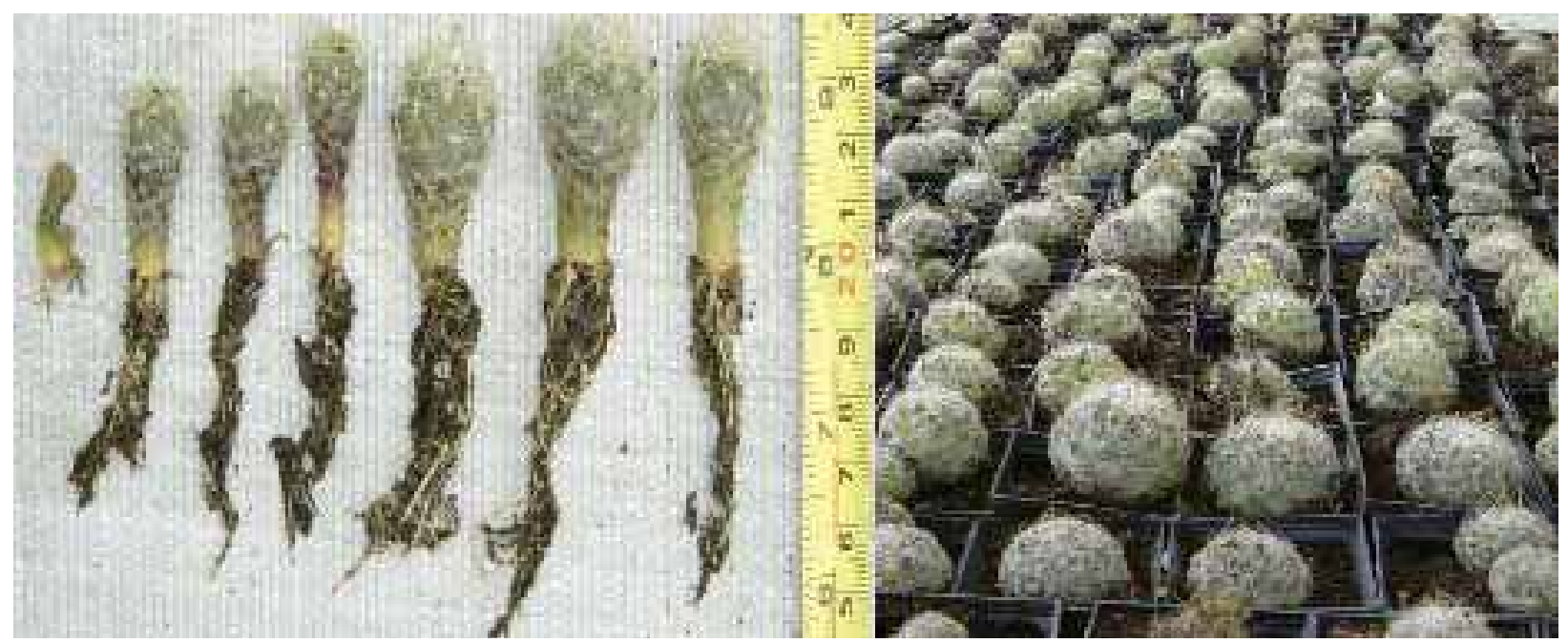

Figura 5. Efecto de Azospirillum brasilense. en el proceso rizogénico de Turbinikarpus knuthianus. Invernadero del Campo Experimental Saltillo CIRNE-INIFAP.

Figure 5. Effect of Azospirillum brasilense in rhizogenic process of Turbinicarpus knuthianus. Campo Experimental Saltillo CIRNE-INIFAP. 
Longitud de raíces (LR). La interacción SxCONC, presentó diferencias significativas, $y$ con el sustrato poroso (ST =arena) se obtuvo una LR (LR= $3 \mathrm{~cm}$ ) superior al resto de los sustratos, por lo que se infiere que puede utilizarse cepa de $A$. brasilense para el enraizamiento y aclimatación de T. knuthianus, ya que entre la planta y la bacteria se verifica una "simbiosis asociativa", que favorece la producción de hormonas de crecimiento, cambios morfológicos y fisiológicos en las cactáceas que a su vez promueven, en menor tiempo, el desarrollo de raíces con mayor crecimiento, lo que influye en la toma de agua y sales minerales (Burdman et al., 2000; Okon y Labandera-González, 1994) (cuadros 5 y 6).

De acuerdo a Kapulnik et al. (1985), la aplicación de

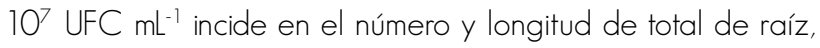
en tanto que la inoculación de $10^{8} \mathrm{UFC} \mathrm{mL}^{-1}$ causa la inhibición de desarrollo. El efecto rizogénico es similar al consignado por otros autores; al trabajar con Pachycereus pringlei (S. Watson) Britton et Rose, la concentración de $1.5 \times 10^{6}$ UFC L-1 de Azospirillum spp. inoculado a un suelo pobre de áreas desérticas, incrementa la materia vegetativa hasta un $60 \%$ y el largo de las raíces en un $100 \%$. Para el caso de T. knuthianus se determinó que la bacteria invadió el sistema radical del cactus, durante los primeros 30 días de aclimatación considerando este tiempo como un período de adaptación (Pacovsky et al., 1985; Puente y Bashan, 1993).

Supervivencia. El crecimiento ex vitro es autotrófico, y no heterotrófico como en condiciones in vitro, por lo que es necesario reconstruir y desarrollar procesos y estructuras adaptativos como lignificación, cubiertas cuticulares, estomas y órganos fotosintéticos para que las plantas tengan un desarrollo autónomo, mismo que ocurre durante la aclimatación. Al respecto, se obtuvieron diferencias significativas entre sustratos con y sin inoculación de la cepa; las plantas que fueron aclimatadas con la interacción de la cepa registraron una supervivencia mayor al $91 \%$, independientemente del tipo de sustrato, mientras que sus homólogos sin la cepa sólo alcanzaron un valor promedio de $72 \%$ y el tratamiento $\mathrm{T} 10$ presentó mayor contenido de humedad lo cual provocó un incremento en la pudrición de las plantas (Cuadro 8 y Figura 6). Trinidad (2005) cita el mismo efecto en T. knuthianus con un porcentaje bajo de supervivencia $(60 \%)$.

A pesar de que se trata de un sustrato estéril comúnmente usado en plantas ornamentales de tallo suculento, los resultados muestran que para la especie de interés es poco recomendable, ya que sus requerimientos de humedad son bajos. T. knuthianus es una planta propia de condiciones semiáridas, por lo que se propone utilizar un sustrato poroso como lo refieren Johnson y Emino ( 1979 b). Los tratamientos T1 y T5 tuvieron un efecto positivo en la aclimatación, si se inocula con una cepa rizogénica, en ambos casos se observó una sobrevivencia estadísticamente igual (90\%).
Root length (LR). The SxCONC interaction showed significant differences, and with the porous substrate $(S I=s a n d) L R$ was higher than the rest of the substrates $(L R=3 \mathrm{~cm})$, from which it can be inferred that $A$. brasiliense may be used for the rooting and acclimatization of $T$. knuthianus, since an "associative symbiosis" takes place between the plant and the bacterium which favors the production of growth hormones, morphologic and physiologic changes in cacti that promote, as well, in a shorter time, the development of roots with greater growth, which influences water and mineral salts uptake (Burdman et al., 2000; Okon and Labandera-González, 1994) (Tables 5 and 6).

According to Kapulnik et al. (1985), the application of

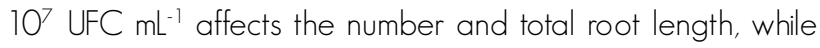
the inoculation with $10^{8} \mathrm{UFC} \mathrm{mL}^{-1}$ causes development inhibition. The rhizogenic effect is similar to that reported by other authors; when testing Pachycereus pringlei (S. Watson) Britton et Rose with an Azospirillum spp. concentration of $1.5 \times 10^{6}$ UFC L-1, inoculated to a poor soil of desert lands, green matter increases up to $60 \%$ and root length, $100 \%$. For T. knuthianus it was determined that the bacterium invaded the root system of the cactus during the first 30 days of acclimatization, taking this time as an adaptation period (Pacovsky, et al., 1985; Puente and Bashan, 1993).

Survival. Ex vitro growth is autotrophic, and not heterotrophic as in vitro, which makes it necessary to reconstruct and develop processes and adaptive structures such as lignification, cuticular covers, stomas and photosynthetic organs for an autonomous development of plants, which takes place during acclimatization. In this regard, significant differences were obtained between substrates with or without inoculation of strains; the plants that were acclimatized with the strains interaction registered a survival over $91 \%$, regardless of the substrate, while their homologous without strains showed an average value of $72 \%$ and the 110 treatment, a higher humidity content, which produced an increment in plant rottenness (Table 8 and Figure 6). Trinidad (2005) describes the same effect for $T$. knuthianus with a low survival per cent $(60 \%)$.

In spite of being a sterile substrate regularly used in ornamental plants of succulent stem, results show that for the studied species it is not advisable, since its moisture requirements are low. T. knuthianus lives in a semi-arid environment, which suggests the convenience of using a porous substrate (Johnson and Emino, 1979b). The $\mathrm{Tl}$ and $\mathrm{T} 5$ treatments had a positive effect on acclimatization if inoculation is includes a rhizogenic strain; in both cases, survival was statistically the same (90\%).

These results show the ability that in vitro cultivated plants have to control water loss through activation of their stomata (Santamaría et al., 1995; Santamaría, 1996) and that the morpho-physiologic behavior and the biochemistry 


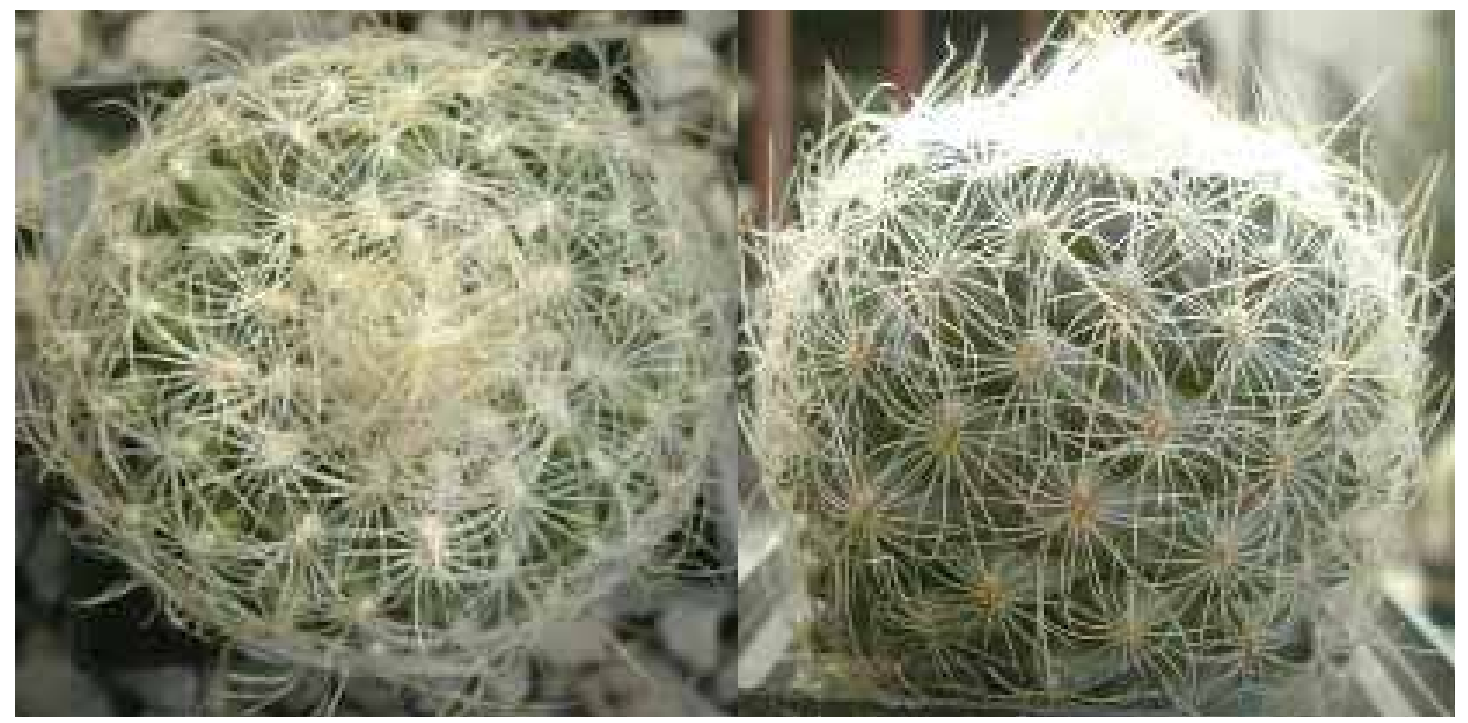

Figura 6. Planta aclimatada de Turbinicarpus knuthianus. a los 90 días de desarrollo en condiciones de invernadero, inoculadas con Azospirillum brasilense.

Figura 6. Acclimatized Turbinicarpus knuthianus plants after 90 days of development under greenhouse environment inoculated with Azospirillum brasilense.

Estos resultados muestran la capacidad que tienen las plantas cultivadas in vitro para controlar la pérdida de agua a través de la activación de sus estomas (Santamaría et al., 1995; Santamaría, 1996), y que el comportamiento morfo-fisiológico y la bioquímica de las plántulas aclimatadas dependen de las condiciones hetero-mixotróficas a las que están expuestas durante este proceso.

\section{CONCLUSIONES}

En especies con un número reducido de semillas, como es el caso de T. knuthianus, la perdida de plántulas limita su regeneración en condiciones controladas, por lo que la selección del medio de cultivo es importante en la etapa de establecimiento, dado que su efecto se refleja en las siguientes fases de la micropropagación.

La micropropagación es un método factible para regenerar especies de cactáceas, involucra cuatro etapas en las cuales se pueden producir vitroplantas de tamaño uniforme y con buena calidad fitosanitaria. Mediante el cultivo de tejidos vegetales y el uso de microorganismos promotores del crecimiento de las plantas, se pueden optimizar procesos biológicos de este tipo de especies de importancia ecológica y económica.

El uso de rizobacterias es una alternativa exitosa para la aclimatación de T. knuthianus, ya que mantiene la fertilidad del suelo, sin causar contaminación ambiental. of acclimatized seedlings depend on the hetero-mixotrophic conditions to which they are exposed during this process.

\section{CONCLUSIONS}

In species with a small amount of seeds, as $T$. knuthianus, the loss of seedlings limits its regeneration under control conditions; thus, the selection of culture medium is important in the establishment stage, since their effect affects the following micropropagation phases.

Microprogapagation is a feasible method to regenerate cacti species involves four stages, in which vitro-plants of a uniform size and with good phytosanitary quality may be produced. By means of vegetal tissue culture and the use of microorganisms that promote growth in plants, biological process of this kind of species of ecological and economic importance might be optimized.

The use of rhizobacteria is a successful option for the acclimatization of $T$. knuthianus, since it holds soil fertility without causing environmental pollution.

\section{ACKNOWLEDGEMENTS}

The authors acknowledge CONAFOR-CONACYT for having sponsored the CO3- 10569 project, as well as to the Fundación Produce Coahuila A. C. and to SNICS-SINAREFI for the support that gave birth to the actual work. Also to the Comisariados ejidales and to the producers of the different municipalities of San Luis Potosí State for their help and the facilities that they provided to accomplish the field work.

End of the English version 


\section{AGRADECIMIENTOS}

Los autores expresan su reconocimiento al fondo sectorial CONAFORCONACYT por el financiamiento del proyecto CO3-10569, así como a la Fundación Produce Coahuila A. C. y al SNICS-SINAREFI por el apoyo que dio origen al presente trabajo. También se agradece a los Comisariados ejidales y productores de los diferentes municipios de San Luís Potosí por su colaboración y facilidades brindadas para los trabajos de campo.

\section{REFERENCIAS}

Araya E., L. Gómez, N. Hidalgo y R. Valverde. 2000. Efecto de la luz y del acido giberélico sobre la germinación in vitro de jaul (Alnus acuminatay) Agronomia Costarricense 24(1): 75-80.

Burdman S., Y. Okon and E. Jurkevitch. 2000. Surface characteristics of Azospirillum brasilense in relation to cell aggregation and attachment to plant roots. Crit. Rev. Microbiol. Vol 26:91- 110.

Canto M., J. C., S. Medina P. y D. Morales A. 2004. Efecto de la inoculación con Azospirillum sp. en plantas de chile Habanero (Capsicum chinese Jacquin). Tropical and Subtropical Agroecosystems 4(1): 21-27.

Carletti S., M., E. Rodríguez C. A. y E. Llorente B. 2003. Rizobacterias promotoras del crecimiento vegetal en la micropropagación de plantas. In: Albanesi, A., A. Anriquez, S. Luna, C. Kunst y R. Ledesma (Eds.). Microbiología Agrícola. Un aporte de la investigación Argentina. Universidad Nacional de Santiago del Estero. Ciudad Santiago del Estero, Argentina. pp. 119-129.

Clayton, P. W., J. F. Hubstenberger and G. Phillips C. 1990. Micropropagation of members of the Cactaceae subtribe Cactinae. J. Amer. Soc. Hor. Sci. 115(2):337-343.

Dabekaussen, M. A. A., R. L. M. Pierik, J. D. Van der Laken and J. Hoek Spaans. 1991. Factors affecting areole activation in vitro in the cactus Sulcorebutia alba. Rausch. Sci. Hort. 46:283-294.

Dávila, F. C. A., De La Rosa, C. M. L., Pére, M. B. 2005. In vitro propagation of eight species or subspecies of Turbinicarpus (Cactaceae). In Vitro Cellular and Developmental Biology-Plant 41: 540-545.

De La Rosa-lbarra M, García H. 1994. Estimulación de la germinación de cinco especies de cactáceas consideradas en peligro de extinción. PhytonInt. J. Exp. Bot. 56: 147- 150.

De la Vega, B. y R. Alizaga, 1987. Efecto del ácido giberélico y del preenfriamiento sobre la ruptura del reposo en semillas de salvia. Agronomía Costarricense. 11 (1): 89-95.

Díaz-Zorita, M., R. Ballina, M. Fernández C., C. Penna and A. Perticari A. 2004. Field inoculation of wheat (Triticum aestivum L.) and corn (Zea mays L.) with Azospirillum brasilense in the Pampas region, Argentina. 22nd Latin American Conference on Rhizobiology. Brasil. Journal of Soil Biology 45: 28-35.

Dutra D., R. Timothy J., P. J. Kauth, L. Scott S., M. E. Kane and L. Richardson 2008. Asymbiotic seed germination, in vitro seedling development, and greenhouse acclimatization of the threatened terrestrial orchid Bletia purpurea. Plant Cell Tiss Organ Cult. 94: 11-21.

Escobar H., A. 1985. Micropropagación y almacenamiento in vitro de Opuntia amyclaea Tenore. Tesis de Maestría en Ciencias. Colegio de Postgraduados. Montecillo, Edo. de México. México. 80 p.

Fay, M. F. and J. Gratton. 1992. Tissue culture of cacti and other succulents: a literature review and a report on micropropagation at Kew. Bradleya. 10: $33-48$.

Giusti, P., D. Vitti, F. Fiocchetti, G. Colla, F. Saccardo and M. Tucci. 2002. In vitro propagation of three endangered cactus species. Scientia Horticulturae 95(4): 319-332

Hubstenberger J. F. P., W. Clayton and G. Phillips C. 1992. Micropropagation of Cacti (Cactaceae) IV. Biotechnology in Agriculture and Forestry 20:49-68.

Hunt, D., N. Taylor and G. Charles (Eds.) 2006. The New Cactus Lexicon. Descriptions and illustrations of the cactus family. International Cactaceae Systematic Group. DH Books. UK. Vol. I, 375 p.

Johnson J. L. and E. Emino R. 1979a. Tissue culture propagation of cacti. Cact. Succ. J. (US) 51: 275-277.
Johnson J. L. and E. Emino R. 1979b. In vitro propagation of Mammillaria elongata. Hort Science 14(5): 605-606.

Kapulnik Y., Y. Okon and Y. Henis. 1985. Changes in root morphology of wheat caused by Azospirillum inoculation. Can. J. Microbiol. 31:881-887.

Kauth ,J. P., A. Wagner V. and E. Michael K.2006. In vitro seed culture and seedling development of Calopogon tuberosus. Plant Cell Tissue and Organ Culture. 85(1): 91- 102.

Maiti R., K., P. Hernández J. L. and M. Valdez M. 1994. Seed ultraestructure and germination of some species of Cactaceae. Phyton No. 55 pp. 97-105.

Malda, G., H. Suzan and R. Backhaus. 1999. In vitro culture as a potential method for the conservation of endangered plants possessing crassulacean acid metabolism. Sci Hortic 81(1):71-87.

Martínez V., O. and A. Rubluo. 1989. In vitro mass propagation of the nearextinct Mammillaria san-angelensis Sánchez-Mejorada. J. Hort. Sci. $61(1): 99-105$.

Mata, R. M., M. Monroy-De La Rosa, K. M. Goldammer and V.M Chávez-Ávila. 2001. Micropropagation of Turbinicarpus laui Glass et Foster, an endemic and endangered species. In Vitro Cellular and Developmental Biology-Plant 37: 400-404

Mauseth, D. J. 1976. Cytokinin and gibberellic acid-induced effects on the structure and metabolism of shoot apical meristems In: Opuntia polyacantha (cactaceae). Amer. J. Bot. 63 (10): 1295- 1301.

Mauseth, D., J. 1978. An investigation of the phylogenetic and ontogenetic variability of shoot apical meristems in the Cactaceae. Amer. J. Bot. 65(3): 326-333.

Mauseth, D. J. 1979. A new method for the propagation of cacti: sterile culture of axillary buds. Cact. and Succ. J. (51): 186- 187.

Moebius-Goldammer K., M. Goldammer, R. Mata M. and V. Chávez M. 2003. Organogenesis and somatic embryogenesis in Ariocarpus kotschoubeyanus (Lem.) K. Schum. (Cactaceae), an endemic and endangered Mexican species. In Vitro Cellular and Developmental Biology-Plant 39(4): 388-393.

Murashige, T. and F. Skoog. 1962. A revised medium of rapid growth and bioassays with tobacco cultures. Physiol. Plant 15: 473-497-

Murashige, T. 1974. Plant propagation through tissue cultures. Ann. Rev. Plant Physiol. 25: 135-166.

Okon, Y. 1985. Azospirillum as a potential inoculant for agriculture. Tends in Biotechnology. pp. 223-228.

Okon, Y. and C. A. Labandera-González. 1994. Agronomic applications of Azospirillum: an evaluation of 20 years worldwide field inoculation. Soil Biol. Biochem. 26: 1591- 1601.

Ordóñez M. M. A.2003. Propagación in vitro de Mammillaria voburnensis Scheer. (Cactaceae) Universidad de San Carlos de Guatemala. Facultad de Ciencias Químicas y Farmacia. Guatemala Guatemala. 70 p.

Pacovsky, R. S., E. A. Paul and G. J. Bethlenfalvay. 1985. Nutrition of sorghum plants fertilized with nitrogen or inoculated with Azospirillum brasilense. Plant Soil 85: 145-148.

Papafotiou M., G. Balotis N., T. Panayiota L. and J. Chronopoulos. 2001. In vitro plant regeneration of Mammillaria elongata normal and cristate forms. Plant Cell, Tissue and Organ Culture 65: 163-167, 2001.

Pelah D., R. Kaushik A., Y. Mizrahi and Y. Sitrit. 2002 Organogenesis in the vine cactus Selenicereus megalanthus using thidiazuron. Plant Cell, Tissue and Organ Culture 71: 81-84, 2002.

Pérez, M. B., E. Villalobos, E. Meza E., L. R., Morones and J. Lizalde, 1998. Propagation of 21 species of Mexican cacto by axillary proliferation. In Vitro Cellular and Developmental Biology-Plant 34: 131-135.

Pierik, R. L. M. 1987. In vitro culture of higher plants. Martinus Nijhoff Publishers. Boston, MA USA. pp. 54-82

Puente, M. E. and Y. Bashan. 1993. Effect of inoculation with A. brasilense strains on the germination and seedlings growth of the giant columnar Cardon cactus (Pachycereus pringlei). Symbiosis, 15:49-60.

Rodríguez, G. B. and A. Rubluo. 1992. In vitro morphogenetic responses of the endangered cactus Aztekium ritteri (Boedeker). Cact. Succ. J. 64 (3): 116- 119.

Rojas A., M. 2008. Efecto del ácido giberélico en la germinación de cuatro especies del género Mammillaria del Valle de Tehuacán-Cuicatlán, México. Bol. Soc. Latin. Carib, Cact. Suc. 5(1), 21-23 
Santamaría, J. M., W. J. Davies, and C. J. Atkinson. 1993. Stomata of micropropagated delphinium plants respond to $\mathrm{ABA}, \mathrm{CO}_{2}$, light and water potential, but fail to close fully. Journal of Experimental Botany. Vol. 44. (258) pp. 99- 107.

Santamaría, J. M., J. L. Herrera and M. L. Robert. 1995. Stomatal physiology of micropropagated CAM plant: Agave tequilana (Weber). Plant Growth Regulation. 16: $211-214$.

Secretaría de Medio Ambiente y Recursos Naturales (SEMARNAT). 2010 Norma Oficial Mexicana NOM-059-ECOL-2010. Secretaría de Medio Ambiente y Recursos Naturales. Anexo Normativo II. http://www.ine.gob.mx veajei/publicaciones normas/rec_nat/ no_059a2g.html. (4/marzo/2011).

Statistical Analysis System (SAS). 2002. SAS/STAT user's guide. Release 10.0 ed. SAS Inst. Inc., Cary, NC. USA. 1,028 p.

Tomasz P., W., M. Hamerska and M. Wróblewska. 2006. Organogenesis of vegetative shoots from in vitro cultured flower buds of Mammillaria albicoma (Cactaceae). Plant Cell Tiss Organ Cult 87:27-32

Trinidad G., R. 2005. Multiplicación in vitro de Astrophytum myriostigma Lem. y Turbinicarpus knuthianus Boed. y aclimatación de éstas especies y T. lophophoroides Werd. Tesis Licenciatura. Universidad Autónoma Agraria Antonio Narro. División de Agronomía. Buenavista Saltillo, Coah., México. 85 p.

Villalobos A., V. y M. Thorpe. 1985. La micropropagación: conceptos, metodología y resultados. In: Fundamentos y Aplicaciones del cultivo de tejidos en la agricultura. W. Roca CIAT. Bogotá, Colombia. pp. 67-85
Villavicencio G., E. E., A. Cano P. y I. H. Almeyda L. y M. A. Arellano G. 2006. Nueva técnica para la producción comercial del bonete o birrete de obispo (Astrophytum myriostigma Lem.) Cactacea ornamental del desierto Chihuahuense. INIFAP-CIRNE. Campo Experimental Saltillo. Folleto para productores Núm. 12. ISBN 970-43-0118-9 Coahuila, México. $10 \mathrm{p}$.

Villavicencio G., E. E., A. Cano P. y A. Juárez S. 2009. Micropropagación producción de plantas del bonete o birrete de obispo, cactácea ornamental amenazada de extinción del desierto Chihuahuense. Campo Experimental Saltillo. INIFAP-CIRNE. Folleto Técnico Núm 39. ISBN 978-607-425-130-2 Coahuila, México. 42 p.

Villavicencio G., E. E., A. Arredondo G., M. A. Carranza P., O. Mares A., S. Comparan S. y A. González C. 2010 Cactáceas ornamentales del desierto Chihuahuense que se distribuyen en Coahuila, San Luis Potosí y Nuevo León, México. Libro Técnico No. 2 ISBN: 978607-425-473-0 Campo Experimental Saltillo CIRNE-INIFAP, Saltillo Coahuila, México. 345 p.

Vyskot, B. and Z. Jara. 1984. Clonal propagation of cacti through axillary buds in vitro. J. Hort. Sci. 59(3): 449-452.

Yassen-Mohamed, Y., S. Barringer A., W. Splittstoesser E. and R. J. Schnell. 1995. Rapid propagation of tuna (Opuntia ficus indica) and plant establishment in soil. Plant Cell Tissue and Organ Culture 42: 117- 119. 